\title{
WILEY-VCH
}

DOI: 10.1002/ ((please add manuscript number))

Article type: Full Paper

\section{Function Follows Form: Correlation Between the Growth and Local Emission of Perovskite Structures, and the Performance of Solar Cells}

M. Ibrahim Dar, * Alexander Hinderhofer, Gwenole Jacopin, Valentina Belova, Neha Arora, Shaik Mohammed Zakeeruddin, Frank Schreiber, Michael Grätzel

Dr. M. I. Dar, Dr. N. Arora, Dr. S. M. Zakeeruddin, Prof. M. Grätzel

Laboratory of Photonics and Interfaces, Institute of Chemical Sciences and Engineering, École Polytechnique Fédérale de Lausanne, CH-1015-Lausanne, Switzerland.

Dr. A. Hinderhofer, V. Belova, Prof. F. Schreiber

Institut für Angewandte Physik, Universität Tübingen, 72076 Tübingen, Germany

Dr. G. Jacopin

Laboratory of Quantum Optoelectronics, Institute of Condensed Matter Physics, École Polytechnique Fédérale de Lausanne, Lausanne CH-1015, Switzerland

E-mail: ibrahim.dar@epfl.ch

Keywords: Perovskite solar cells, Cathodoluminescence, Electron microscopy, X-ray scattering, Photovoltage

Understanding the relation between the growth and local emission of hybrid perovskite structures, and the performance of the devices based on them demands attention. In this study, we have investigated the local structural and emission features of $\mathrm{CH}_{3} \mathrm{NH}_{3} \mathrm{PbI}_{3}$, $\mathrm{CH}_{3} \mathrm{NH}_{3} \mathrm{PbBr}_{3}$ and $\mathrm{CH}\left(\mathrm{NH}_{2}\right)_{2} \mathrm{PbBr}_{3}$ perovskite films deposited under different yet optimized conditions using X-ray scattering and cathodoluminescence spectroscopy, respectively. X-ray scattering shows that $\mathrm{CH}_{3} \mathrm{NH}_{3} \mathrm{PbI}_{3}$ film involving spin coating of $\mathrm{CH}_{3} \mathrm{NH}_{3} \mathrm{I}$ instead of dipping is composed of perovskite structures exhibiting a preferred orientation with [202] direction perpendicular to the surface plane. The device based on the $\mathrm{CH}_{3} \mathrm{NH}_{3} \mathrm{PbI}_{3}$ film composed of oriented crystals yield a higher photovoltage. In case of $\mathrm{CH}_{3} \mathrm{NH}_{3} \mathrm{PbBr}_{3}$, while the crystallinity decreases when the $\mathrm{HBr}$ solution is used in a single-step method, the photovoltage enhancement from 1.1 to $1.46 \mathrm{~V}$ seems largely stemming from the morphological improvements, i.e. a better connection between the crystallites due to a higher nucleation 


\section{WILEY-VCH}

density. Furthermore, a high photovoltage of $1.47 \mathrm{~V}$ obtained from $\mathrm{CH}\left(\mathrm{NH}_{2}\right)_{2} \mathrm{PbBr}_{3}$ devices could be attributed to the formation of perovskite films displaying uniform cathodoluminescence emission. The comparative analysis of the local structural, morphological, and emission characteristics of the different perovskite films support the higher photovoltage yielded by the relatively better performing devices.

\section{Introduction}

Organic-inorganic metal halide perovskites exhibit the general formula $\mathrm{ABX}_{3}$, where $\mathrm{A}$ stands for an organic cation, B stands for $\mathrm{Pb}$ or $\mathrm{Sn}$, and $\mathrm{X}$ stands for a halide anion. ${ }^{[1]} \mathrm{In}$ the recent past, the potential of perovskites as emerging materials in the photovoltaic technology has been demonstrated by certifying record efficiencies. ${ }^{[2,3]}$ The hybrid perovskites exhibit photophysical properties that are suitable for the development of low-cost light harnessing and emitting devices. ${ }^{[4]}$ These salient optoelectronic properties are subservient to the dimensions and morphology of the perovskite structures. ${ }^{[5,6]}$ Therefore, "function follows form" which is an inverse to the guiding principle in architectural endeavors, seems appropriate to explain the upsurge advancement in the performance of perovskite solar cells. $[7,8]$

The growth of perovskite structures has been tailored by optimizing the synthetic and processing approaches. ${ }^{[9]}$ To understand the relation between the chemistry and growth of perovskite structures, various structural and morphological characterization techniques have been explored. The compositional engineering, which falls within the realm of chemistry has been exploited to optimize the bandgap and other desired properties of the hybrid perovskites. ${ }^{[10]}$ However, a slight alteration in the precursor composition or the experimental conditions can influence the growth and formation of perovskite structures immensely. ${ }^{[3]}$ Initially, it was reported that $\mathrm{CH}_{3} \mathrm{NH}_{3} \mathrm{PbI}_{3}$ structures obtained in chloride ambience exhibit improved charge carrier dynamics. ${ }^{[11]}$ Later, we observed that a definite amount of bromide in lead iodide 


\section{WILEY-VCH}

precursor plays a similar role, as the performance of the $\mathrm{CH}_{3} \mathrm{NH}_{3} \mathrm{PbI}_{3}$ devices improved from 14 to $>16 \% .{ }^{[12]}$ Therefore, for a given composition, it becomes imperative to optimize and understand the growth and crystallographic structure of resulting perovskite materials. ${ }^{[13]}$ By changing the lead precursor from halides to acetates, an improvement in the photovoltaic performance has been realized, which was ascribed to the formation of ultra-smooth $\mathrm{CH}_{3} \mathrm{NH}_{3} \mathrm{PbI}_{3}$ films. ${ }^{[14]}$ Fundamentally, the texture of perovskite films depends on the nucleation and growth and to study these processes, X-ray diffraction (XRD) is undoubtedly the technique of choice. Based on the structural characterization by XRD, a strong link between the lateral dimensions of $\mathrm{PbI}_{2}$ and perovskite crystals has been observed. ${ }^{[15]} \mathrm{In}$ further development, while using a real time XRD technique, it was reported that controlling the fractal penetration and orientational transformation observed during the crystallization process of $\mathrm{CH}_{3} \mathrm{NH}_{3} \mathrm{PbI}_{3}$ would allow the fabrication of good quality perovskite films. ${ }^{[16]}$ Furthermore, using in situ XRD to study the crystal growth, the evolution of structure in the $\mathrm{CH}_{3} \mathrm{NH}_{3} \mathrm{PbI}_{3}$ films deposited by the vapor-assisted method was probed. ${ }^{[17]}$ In addition, there are other reports regarding the structural characterization of perovskite structures deposited under various conditions. ${ }^{[18,19,20,21]}$

Despite these reports, which have mostly focused on a particular perovskite system, there is a dearth of studies providing detailed insights regarding the structural and photophysical properties of perovskite films with their impact on the photovoltaic performance of devices. To this end, herein, we examined the local morphology and orientation of three representatives of perovskites, i.e., $\mathrm{CH}_{3} \mathrm{NH}_{3} \mathrm{PbI}_{3}, \mathrm{CH}_{3} \mathrm{NH}_{3} \mathrm{PbBr}_{3}$ and $\mathrm{CH}\left(\mathrm{NH}_{2}\right)_{2} \mathrm{PbBr}_{3}$ grains deposited onto mesoporous $\mathrm{TiO}_{2}$ using field emission scanning electron microscopy and X-ray reciprocal space maps, which allows to determine the distribution of domain orientations. In addition, we studied the emission characteristics of various perovskite films using cathodoluminescence spectroscopy which holds a great potential of bringing out spectral features with a nanometer resolution. ${ }^{[22]}$ Finally, we 


\section{WILEY-VCH}

fabricated devices based on the $\mathrm{CH}_{3} \mathrm{NH}_{3} \mathrm{PbI}_{3}, \mathrm{CH}_{3} \mathrm{NH}_{3} \mathrm{PbBr}_{3}$ and $\mathrm{CH}\left(\mathrm{NH}_{2}\right)_{2} \mathrm{PbBr}_{3}$ perovskite films and correlated their performance with the orientation, morphology, and local emission characteristics of perovskite grains. Overall, this concise and comprehensive study contributes towards understanding the correlation between growth and emission features of perovskite structures with their effect on the efficiency of perovskite light-harnessing and -emitting devices.

\section{Results and Discussion}

Of the various techniques used for the deposition of perovskite films, the films obtained from the solution-based bottom up approaches have been involved in the fabrication of devices displaying record efficiencies. ${ }^{[10]}$ In this study, we employed both single- and two-step solution based methods to deposit different perovskite films onto the mesoporous $\mathrm{TiO}_{2}$ substrates and the conditions optimized for the synthesis are described in the experimental section. The single step method involves the deposition of a mixture of precursors onto a substrate, ${ }^{[23]}$ whereas a two-step approach involves the conversion of lead halide films into perovskite phase by spin coating or dipping into a solution containing a definite amount of organic halide. $^{[2]}$

Table 1. Photovoltaic characteristics. Summary of photovoltaic parameters derived from current-voltage curves (Figure S1, S2, and S3) of different perovskite devices based on $\mathrm{FTO} /$ compact- $\mathrm{TiO}_{2} /$ mesoporous- $\mathrm{TiO}_{2} /$ perovskite/spiro-OMeTAD/Au architecture measured under an illumination intensity of $100 \mathrm{~mW} \mathrm{~cm}^{-2}$.

\begin{tabular}{lllll}
\hline Sample & $\begin{array}{l}\text { Current } \\
\text { density } \\
\left(\mathbf{m A} / \mathbf{c m}^{2}\right)\end{array}$ & $\begin{array}{l}\text { Open } \\
\text { Circuit voltage (mV) }\end{array}$ & $\begin{array}{l}\text { Fill } \\
\text { factor } \\
(\%)\end{array}$ & $\begin{array}{l}\text { Efficiency } \\
(\%)\end{array}$ \\
\hline $\mathrm{CH}_{3} \mathrm{NH}_{3} \mathrm{Pbl}_{3}$ (dipping) & 21.0 & 948 & 71 & 14.1 \\
$\mathrm{CH}_{3} \mathrm{NH}_{3} \mathrm{Pbl}_{3}$ (spining) & 21.8 & 990 & 72 & 15.5 \\
$\mathrm{CH}_{3} \mathrm{NH}_{3} \mathrm{PbBr}_{3}$ (without $\mathrm{HBr}$ ) & 0.73 & 1100 & 54 & 0.4 \\
$\mathrm{CH}_{3} \mathrm{NH}_{3} \mathrm{PbBr}_{3}$ (with $\mathrm{HBr}$ ) & 1.5 & 1462 & 62 & 1.4 \\
$\mathrm{CH}\left(\mathrm{NH}_{2}\right)_{2} \mathrm{PbBr}_{3}$ (DMF) & 7.1 & 1140 & 67 & 5.4 \\
$\mathrm{CH}\left(\mathrm{NH}_{2}\right)_{2} \mathrm{PbBr}_{3}$ (DMF+DMSO) & 6.7 & 1470 & 69 & 6.8 \\
\hline
\end{tabular}




\section{WILEY-VCH}

\section{1. $\mathrm{CH}_{3} \mathrm{NH}_{3} \mathrm{PbI}_{3}$ ( spin coating vs dipping)}

Two different $\mathrm{CH}_{3} \mathrm{NH}_{3} \mathrm{PbI}_{3}$ films were prepared by converting lead iodide films into $\mathrm{CH}_{3} \mathrm{NH}_{3} \mathrm{PbI}_{3}$ phase by spin coating or by dipping into an isopropanol solution containing a definite amount of methylammonium iodide (MAI). ${ }^{[2,5]}$ Based on the resulting $\mathrm{CH}_{3} \mathrm{NH}_{3} \mathrm{PbI}_{3}$ films, the devices with an architecture FTO/compact $\mathrm{TiO}_{2} /$ meso- $^{-\mathrm{TiO}_{2}} / \mathrm{CH}_{3} \mathrm{NH}_{3} \mathrm{PbI}_{3} /$ spiroOMeTAD/Au were fabricated to study the influence of synthetic methodology adopted for the deposition of $\mathrm{CH}_{3} \mathrm{NH}_{3} \mathrm{PbI}_{3}$ films on the photovoltaic performance of the devices. The photovoltaic parameters extracted from current-voltage (J-V) curves (Figure S1) of $\mathrm{CH}_{3} \mathrm{NH}_{3} \mathrm{PbI}_{3}$ devices are summarized in Table 1. Under an illumination of $100 \mathrm{~mW} \mathrm{~cm}{ }^{-2}$, the device based on $\mathrm{CH}_{3} \mathrm{NH}_{3} \mathrm{PbI}_{3}$ film involving dipping of $\mathrm{PbI}_{2}$ film into $\mathrm{CH}_{3} \mathrm{NH}_{3} \mathrm{I}$ solution, exhibits a short-circuit current density $\left(\mathrm{J}_{\mathrm{SC}}\right)$ of $21 \mathrm{mAcm}^{-2}$, open-circuit voltage $\left(\mathrm{V}_{\mathrm{OC}}\right)$ of 948 $\mathrm{mV}$, and a fill factor (FF) of 0.71 , resulting in an overall power conversion efficiency $(\eta)$ of $14.1 \%$. On the other hand, the device based on $\mathrm{CH}_{3} \mathrm{NH}_{3} \mathrm{PbI}_{3}$ film involving spin coating of $\mathrm{CH}_{3} \mathrm{NH}_{3} \mathrm{I}$ solution onto $\mathrm{PbI}_{2}$ film, displayed a $\mathrm{J}_{\mathrm{SC}}$ of $21.8 \mathrm{mAcm}^{-2}$, a $\mathrm{V}_{\mathrm{OC}}$ of $990 \mathrm{mV}$, and a FF of 0.72 , resulting in an overall power conversion efficiency $(\eta)$ of $15.5 \%$. The higher efficiency achieved when spin coating strategy was employed arises mainly from a higher $\mathrm{V}_{\mathrm{OC}}($ by $42 \mathrm{mV})$, which is in agreement with the reported literature. ${ }^{[2,5]}$

To correlate the surface morphology of the perovskite films with the performance of devices, we examined both the $\mathrm{CH}_{3} \mathrm{NH}_{3} \mathrm{PbI}_{3}$ films by field emission scanning electron microscopy (FESEM), which establishes that the surface coverage and morphology of the perovskite structures obtained by dipping (Figure 1a) or by spin coating (Figure 1b) is ostensibly quite similar. The morphological analysis also illustrated that both the perovskite films contain densely packed asymmetric $\mathrm{CH}_{3} \mathrm{NH}_{3} \mathrm{PbI}_{3}$ structures with a broad size distribution. 


\section{WILEY-VCH}
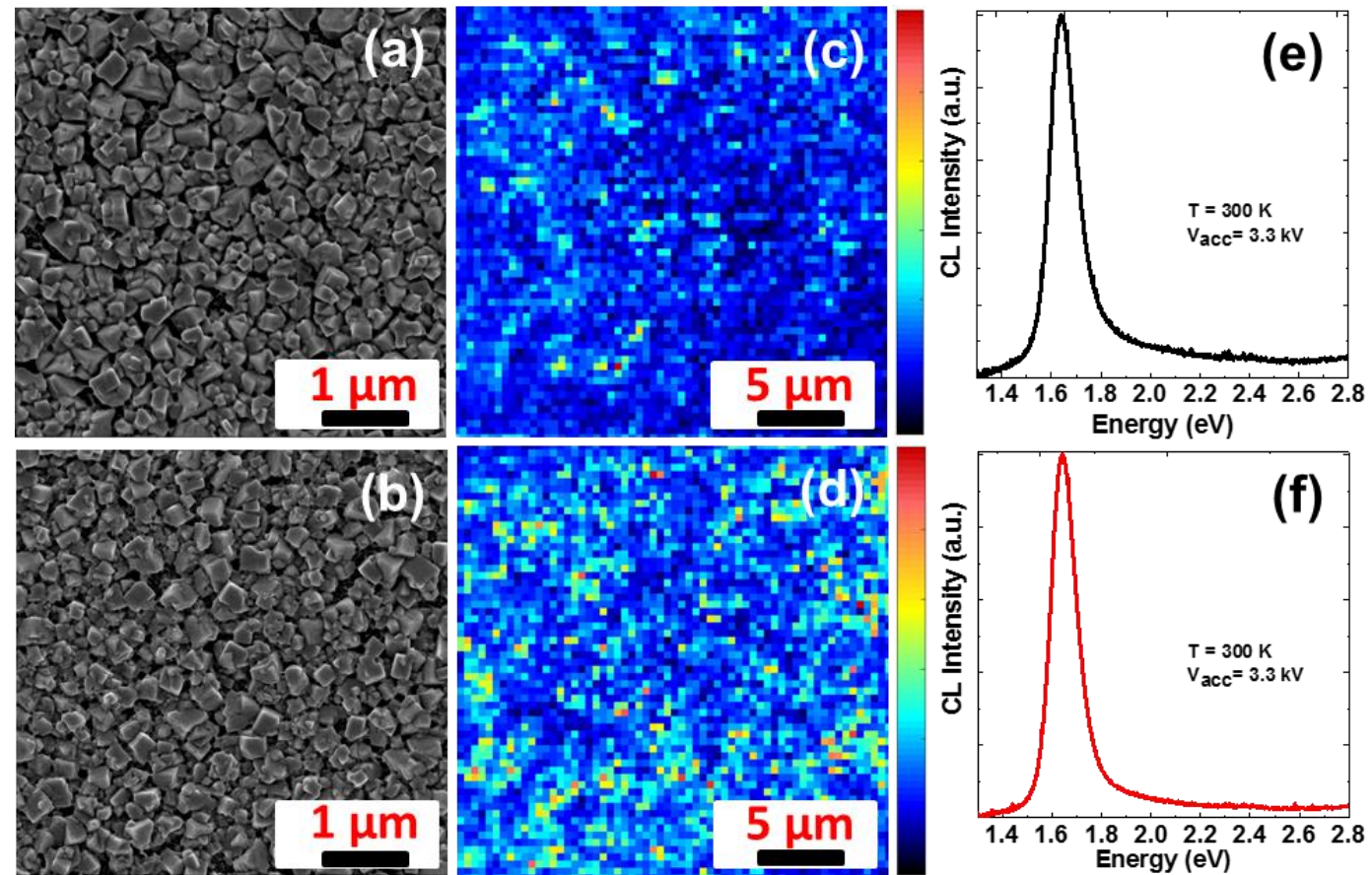

Figure 1. Morphological and cathodoluminescence studies of $\mathrm{CH}_{3} \mathrm{NH}_{3} \mathrm{PbI}_{3}$ films obtained after dipping or spin coating of $\mathrm{CH}_{3} \mathrm{NH}_{3} \mathrm{I}$ solution. (a) SEM micrograph of $\mathrm{CH}_{3} \mathrm{NH}_{3} \mathrm{PbI}_{3}$ film involving dipping. (b) SEM micrograph of $\mathrm{CH}_{3} \mathrm{NH}_{3} \mathrm{PbI}_{3}$ film involving spin coating. (c) cathodoluminescence mapping acquired at $300 \mathrm{~K}$ on $\mathrm{CH}_{3} \mathrm{NH}_{3} \mathrm{PbI}_{3}$ film involving dipping. (d) cathodoluminescence mapping acquired at $300 \mathrm{~K}$ on $\mathrm{CH}_{3} \mathrm{NH}_{3} \mathrm{PbI}_{3}$ film involving spin coating. (e) cathodoluminescence spectrum obtained from $\mathrm{CH}_{3} \mathrm{NH}_{3} \mathrm{PbI}_{3}$ film involving dipping at 300 $\mathrm{K}$ and (f) cathodoluminescence spectrum obtained from $\mathrm{CH}_{3} \mathrm{NH}_{3} \mathrm{PbI}_{3}$ film involving spin coating at $300 \mathrm{~K}$. (cathodoluminescence intensity scale bar is from 0.1 to 1)

From the comparative analysis of photovoltaic characteristics, the major difference observed in the performance stems from the photovoltage (Table 1). In principle, exploring emission characteristics $\mathrm{CH}_{3} \mathrm{NH}_{3} \mathrm{PbI}_{3}$ films can provide direct clues regarding the improvement in $\mathrm{V}_{\mathrm{OC}}$. To examine the local emission characteristics of $\mathrm{CH}_{3} \mathrm{NH}_{3} \mathrm{PbI}_{3}$ structures, we examined the perovskite films using cathodoluminescence (CL). ${ }^{[24]}$ Cathodoluminescence spectroscopy holds a great potential of revealing emission characteristics at the nano-regime, which gives it an edge over other techniques, such as conventional photoluminescence. ${ }^{[25]}$ Figure 1c and Figure 1d display $\mathrm{CL}$ maps obtained from the $\mathrm{CH}_{3} \mathrm{NH}_{3} \mathrm{PbI}_{3}$ films, which were prepared by employing dipping and spin coating conditions, respectively. From CL maps, it is 


\section{WILEY-VCH}

evident that not the entire $\mathrm{CH}_{3} \mathrm{NH}_{3} \mathrm{PbI}_{3}$ films radiate homogeneously, however the film obtained after spin coating $\mathrm{CH}_{3} \mathrm{NH}_{3} \mathrm{I}$ solution exhibits relatively a uniform CL emission.

Figure S4,5 displays a direct correlation between the morphological and emission features. Both the perovskite films exhibit strong and narrow emission spectra (Figure 1e, f) attributable to the band edge transition around $1.65 \mathrm{eV}$ with a linewidth of $125 \mathrm{meV}$. The overall broadening of emission peaks in the perovskites can be explained by involving the temperature-independent inhomogeneous broadening and the interaction between charge carriers and the longitudinal optical phonons. ${ }^{[26]}$ Furthermore, the absence of $\mathrm{PbI}_{2}$ emission peak in the CL spectra (Figure 1e,f) clearly demonstrates the absence of degradation of $\mathrm{CH}_{3} \mathrm{NH}_{3} \mathrm{PbI}_{3}$ material (during the measurement). ${ }^{[27]}$

\subsubsection{Structural characterization}

To further understand and rationally correlate the performance of devices with the orientation and structure of the $\mathrm{CH}_{3} \mathrm{NH}_{3} \mathrm{PbI}_{3}$ grains comprising perovskite films, we employed $\mathrm{X}$-ray scattering. $\mathrm{CH}_{3} \mathrm{NH}_{3} \mathrm{PbI}_{3}$ exhibits three crystallographic phases. ${ }^{[28]}$ At room temperature, the tetragonal phase $(\mathrm{I} / \mathrm{mcm})$ of $\mathrm{CH}_{3} \mathrm{NH}_{3} \mathrm{PbI}_{3}$ is thermodynamically the most stable phase, and transforms into the orthorhombic phase (Pnma) below $160 \mathrm{~K}$, whereas above $330 \mathrm{~K}$, $\mathrm{CH}_{3} \mathrm{NH}_{3} \mathrm{PbI}_{3}$ stabilizes into a cubic phase $(\mathrm{Pm} 3 m) .{ }^{[29]}$ The reciprocal space maps of both $\mathrm{CH}_{3} \mathrm{NH}_{3} \mathrm{PbI}_{3}$ samples (Figure 2) show a diffraction pattern consistent with the tetragonal phase and a polycrystalline nucleation behavior. Bragg peak width and integrated intensities do not vary significantly between both samples leading to the conclusion that the crystal quality is very similar.

Figure S6 (Supporting Information) shows a cut through reciprocal space $\left(\mathrm{q}_{\mathrm{z}}=0\right)$ for both samples and demonstrates that the crystal structure is identical. However, the angular distributions of Bragg peak intensities are strongly different, as shown exemplarily for the 110 $\operatorname{ring}\left(q=1.00 \AA^{-1}\right)$ in Figure 2c. 


\section{WILEY-VCH}
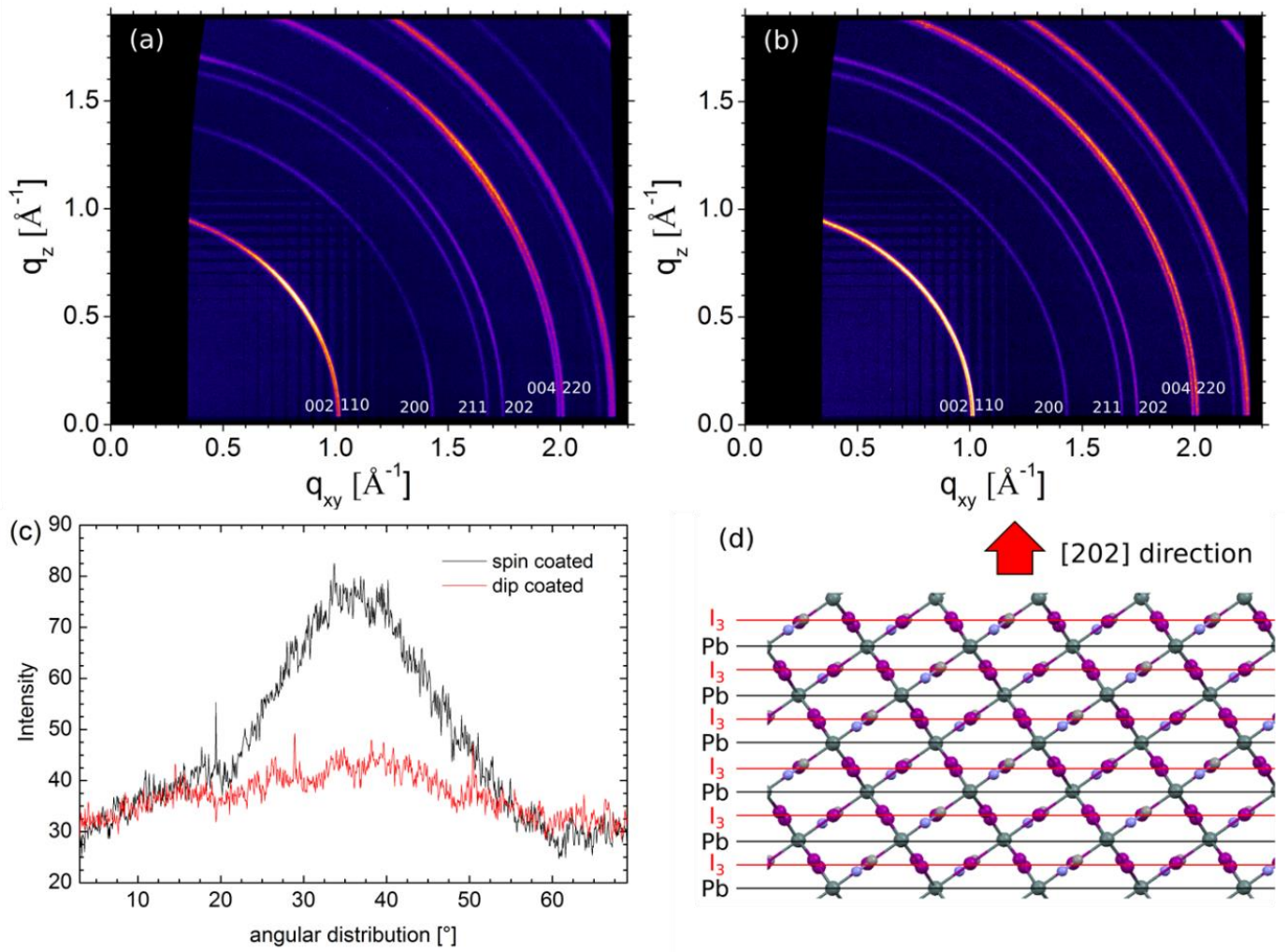

Figure 2. Reciprocal space maps from $\mathrm{CH}_{3} \mathrm{NH}_{3} \mathrm{PbI}_{3}$ films obtained after dipping or spin coating of $\mathrm{CH}_{3} \mathrm{NH}_{3} \mathrm{I}$ solution: (a) spin coating. (b) dip coating. (c) Angular intensity distribution of the 110 Bragg reflection as extracted from (a) and (b), and (d) Sketch illustrating the preferred crystal orientation of the spin coated $\mathrm{CH}_{3} \mathrm{NH}_{3} \mathrm{PbI}_{3}$ film which exhibits alternating layers of $\mathrm{Pb}^{+2}$ and iodide. The [202] direction is perpendicular to the substrate.

The spin-coated sample has clearly a preferred orientation with the 110 plane aligned at $36^{\circ}$ (FWHM: $22^{\circ}$ ) relative to the surface plane. In contrast, the dip-coated sample exhibits a nearly random orientation of crystallites without a clearly defined intensity maximum. From the analysis of intensity distributions of additional reflections, we can conclude that the preferred orientation in the spin coated sample is with the [202] direction perpendicular to the sample plane (Figure 2d). For this crystal orientation, we have alternating layers of $\mathrm{Pb}$ and I parallel to sample plane. Apparently, the CL emission characteristics and the crystallographic orientation of perovskite crystal structures seem to be correlated, which perhaps could explain a higher photovoltage obtained when spin coating conditions were used. 


\section{WILEY-VCH}

\section{2. $\mathrm{CH}_{3} \mathrm{NH}_{3} \mathrm{PbBr}_{3}$ (role of $\mathrm{HBr}$ )}

We further extended our investigation towards $\mathrm{CH}_{3} \mathrm{NH}_{3} \mathrm{PbBr}_{3}$ system, another representative of organic-inorganic lead halide perovskite family. Bromide-based perovskites exhibiting relatively wider bandgaps can be used in tandem solar cells and in driving electrochemical reactions which require high voltages. ${ }^{[30]}$ Earlier, Im and co-workers demonstrated that a definite amount of $\mathrm{HBr}$ in the perovskite precursor solution could improve the coverage of $\mathrm{CH}_{3} \mathrm{NH}_{3} \mathrm{PbBr}_{3}$ films, thus the photovoltaic performance of the devices. ${ }^{[31]}$ Here, we also adopted a single-step approach and prepared $\mathrm{CH}_{3} \mathrm{NH}_{3} \mathrm{PbBr}_{3}$ films with and without adding $\mathrm{HBr}$ to the precursor solutions while retaining the mesoscopic architecture. The currentvoltage (J-V) curves of $\mathrm{CH}_{3} \mathrm{NH}_{3} \mathrm{PbBr}_{3}$ devices recorded under Air-Mass 1.5 global (AM 1.5G) illumination are shown in Figure S2 (Supporting Information). The device containing the $\mathrm{CH}_{3} \mathrm{NH}_{3} \mathrm{PbBr}_{3}$ film prepared in absence of $\mathrm{HBr}$ exhibits relatively low photovoltaic parameters, such as $\mathrm{V}_{\mathrm{OC}}$ of $1100 \mathrm{mV}$ (Table 1). On the contrary, the device based on $\mathrm{CH}_{3} \mathrm{NH}_{3} \mathrm{PbBr}_{3}$ film involving $\mathrm{HBr}$, exhibits a remarkable $\mathrm{V}_{\mathrm{OC}}$ of $1462 \mathrm{mV}$. The $\mathrm{J}_{\mathrm{SC}}$ obtained in our case is quite low as compared to that reported by Im and co-workers, ${ }^{[31]}$ which probably stems from the low loading of the perovskite as we used a different device architecture. It is worth emphasizing that our study focuses on understanding the origin of high $\mathrm{V}_{\mathrm{OC}}$, which apparently is close to the reported values.

Furthermore, from high magnification SEM micrographs, it is quite evident that the coverage of $\mathrm{CH}_{3} \mathrm{NH}_{3} \mathrm{PbBr}_{3}$ film obtained in the absence of $\mathrm{HBr}$ is relatively poor (Figure 3a), whereas the formation of a uniform $\mathrm{CH}_{3} \mathrm{NH}_{3} \mathrm{PbBr}_{3}$ films was realized, when $\mathrm{HBr}$ was added to the precursor solution (Figure 3b). We assume that the presence of $\mathrm{HBr}$ increases the nucleation density which eventually promotes the formation of $\mathrm{CH}_{3} \mathrm{NH}_{3} \mathrm{PbBr}_{3}$ films with improved surface coverage. Moreover, the photovoltaic parameters clearly display that the addition of $\mathrm{HBr}$ to the $\mathrm{CH}_{3} \mathrm{NH}_{3} \mathrm{PbBr}_{3}$ precursor solution leads to the realization of significantly high photovoltage. Such an enhancement of $\mathrm{V}_{\mathrm{OC}}$ from 1100 to $1465 \mathrm{mV}$ 


\section{WILEY-VCH}

ostensibly could be ascribed to the uniform distribution of perovskite structures over the substrates. However, to further unravel the role of $\mathrm{HBr}$, we recorded CL from the controlled and $\mathrm{CH}_{3} \mathrm{NH}_{3} \mathrm{PbBr}_{3}$ films obtained in the presence of $\mathrm{HBr}$. CL mapping revealed that the controlled $\mathrm{CH}_{3} \mathrm{NH}_{3} \mathrm{PbBr}_{3}$ films exhibit a strong but highly non-uniform emission (Figure 3c), whereas $\mathrm{CH}_{3} \mathrm{NH}_{3} \mathrm{PbBr}_{3}$ films obtained in the presence of $\mathrm{HBr}$ radiate more uniformly (Figure 3d). The CL emission completely follows the morphological features (Figure S7). Arguably, such a contrast in the emission features can translate into a higher photovoltage. Both perovskite films exhibit strong and narrow emission spectra (Figure 3e,f) around $2.3 \mathrm{eV}$ with a linewidth of $115 \mathrm{meV}$, in agreement with the band gap of $\mathrm{CH}_{3} \mathrm{NH}_{3} \mathrm{PbBr}_{3}$. As compared to $\mathrm{CH}_{3} \mathrm{NH}_{3} \mathrm{PbI}_{3}$, the narrow linewidth observed in $\mathrm{CH}_{3} \mathrm{NH}_{3} \mathrm{PbBr}_{3}$ could be due to the weaker electron-phonon interactions. ${ }^{[26]}$
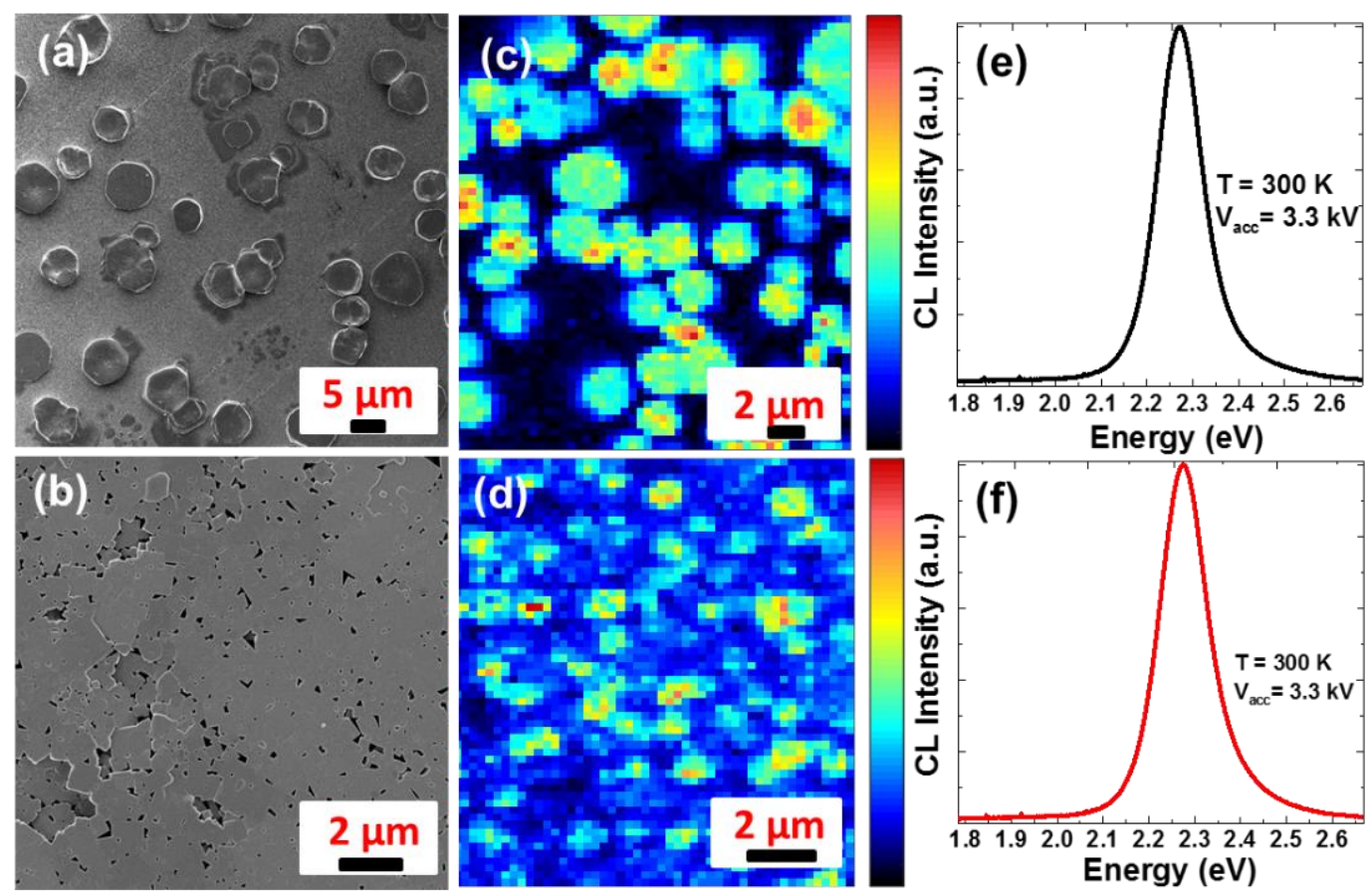

Figure 3. Morphological and cathodoluminescence studies of $\mathrm{CH}_{3} \mathrm{NH}_{3} \mathrm{PbBr}_{3}$ film obtained in the absence or presence of $\mathrm{HBr}$ (a) SEM image of $\mathrm{CH}_{3} \mathrm{NH}_{3} \mathrm{PbBr}_{3}$ film. (b) SEM image of $\mathrm{CH}_{3} \mathrm{NH}_{3} \mathrm{PbBr}_{3}$ film involving $\mathrm{HBr}$. (c) cathodoluminescence mapping acquired at $300 \mathrm{~K}$ on $\mathrm{CH}_{3} \mathrm{NH}_{3} \mathrm{PbBr}_{3}$ film. (d) cathodoluminescence mapping acquired at $300 \mathrm{~K}$ on $\mathrm{CH}_{3} \mathrm{NH}_{3} \mathrm{PbBr}_{3}$ film involving $\mathrm{HBr}$. (e) cathodoluminescence spectrum obtained from $\mathrm{CH}_{3} \mathrm{NH}_{3} \mathrm{PbBr}_{3}$ film at $300 \mathrm{~K}$ and (f) cathodoluminescence spectrum obtained from $\mathrm{CH}_{3} \mathrm{NH}_{3} \mathrm{PbBr}_{3}$ film involving $\mathrm{HBr}$ at $300 \mathrm{~K}$. (cathodoluminescence intensity scale bar is from 0.1 to 1) 


\section{WILEY-VCH}

\subsubsection{Structural characterization}

Unlike $\mathrm{CH}_{3} \mathrm{NH}_{3} \mathrm{PbI}_{3}$ which crystallizes in a tetragonal structure, $\mathrm{CH}_{3} \mathrm{NH}_{3} \mathrm{PbBr}_{3}$ exhibits a cubic phase $(P m 3 m)$ at room temperature, which could be ascribed to the difference in the ionic radii of halide ions. ${ }^{[32]}$ By lowering the temperature, the cubic phase of $\mathrm{CH}_{3} \mathrm{NH}_{3} \mathrm{PbBr}_{3}$ transforms into a tetragonal phase $(\mathrm{L} / \mathrm{mcm})$ at $236 \mathrm{~K}$ and below $150 \mathrm{~K}$, the existence of a low temperature orthorhombic phase $\left(\mathrm{Pna}_{1}\right)$ is expected. ${ }^{[33]}$ Reciprocal space maps of $\mathrm{CH}_{3} \mathrm{NH}_{3} \mathrm{PbBr}_{3}$ prepared without $\mathrm{HBr}$ (Figure 4a) and with $\mathrm{HBr}$ (Figure 4b) exhibit diffraction patterns consistent with the cubic structure. In the sample without $\mathrm{HBr}$, all rings show clearly a sub-structure of minima and maxima. This is a hint that the crystalline domains are relatively large in the range of the scattering volume. Each maximum belongs to one crystalline domain with a specific orientation and not all possible crystal orientations are present in the scattering volume. The scattering volume for the synchrotron beam on the film surface was in the range of $10^{6} \mu \mathrm{m}^{3}$ leading to the assumption that each crystalline domain should have a size of several $\mu \mathrm{m}$. This leads to the assumption that the crystallites in Figure 3a are really single crystalline domains. By evoking the randomly oriented aggregation type growth mechanism, the formation of single crystalline domains of $\mathrm{CH}_{3} \mathrm{NH}_{3} \mathrm{PbBr}_{3}$ prepared in the absence of $\mathrm{HBr}$ can be explained. ${ }^{[9]}$
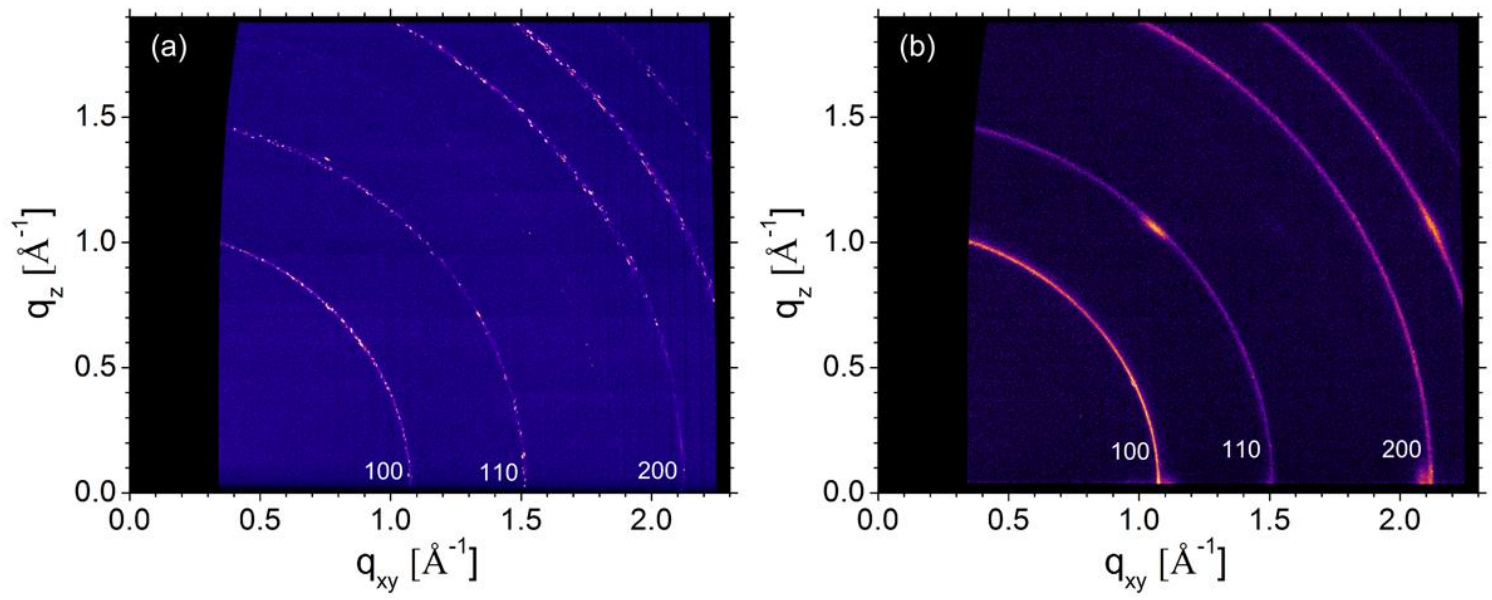

Figure 4. Reciprocal space maps from $\mathrm{CH}_{3} \mathrm{NH}_{3} \mathrm{PbBr}_{3}$ deposited using different conditions: (a) without $\mathrm{HBr}$ and (b) with $\mathrm{HBr}$. 


\section{WILEY-VCH}

By contrast, in the $\mathrm{CH}_{3} \mathrm{NH}_{3} \mathrm{PbBr}_{3}$ film prepared with $\mathrm{HBr}$, the crystallite size is much smaller as revealed by the continuous diffraction rings and the peak widths. Calculating the typical coherently scattering crystallite size $l$ from the peak width via $l=2 \pi / \Delta q$ yields $l=18 \mathrm{~nm}$ for the sample with $\mathrm{HBr}$ and $l>40 \mathrm{~nm}$ for samples without $\mathrm{HBr}$, which corresponds to the resolution limit of our measurement. The formation of sub $40 \mathrm{~nm}$ crystallites supports the assumption that $\mathrm{HBr}$ enhances nucleation density.

\section{3. $\mathrm{CH}\left(\mathrm{NH}_{2}\right)_{2} \mathrm{PbBr}_{3}$ (influence of solvent)}

In solution based bottom-up approaches, solvent plays a critical role in achieving a rational control over the morphology and quality of the perovskite films. ${ }^{[8]}$ To understand the effect of solvent on the growth, emission characteristics and the performance of devices, we prepared two $\mathrm{CH}\left(\mathrm{NH}_{2}\right)_{2} \mathrm{PbBr}_{3}$ films from $\mathrm{PbBr}_{2}$ (DMF) and $\mathrm{PbBr}_{2}$ (DMF+DMSO) solutions using sequential deposition approach as reported in the literature. ${ }^{[34]}$ Previously, it has been reported that DMSO solvent has a tendency to form an adduct with lead iodide and while employing such adducts, the fabrication of high-efficiency solar cells was reported. $[12,35,36,37,38]$ Under standard illumination, devices based on $\mathrm{CH}\left(\mathrm{NH}_{2}\right)_{2} \mathrm{PbBr}_{3}$ films prepared when a single solvent (DMF) was used for the deposition of $\mathrm{PbBr}_{2}$, yielded a $\mathrm{V}_{\mathrm{OC}}$ of $1140 \mathrm{mV}$,

(Table 1), whereas, under similar conditions, devices based on $\mathrm{CH}\left(\mathrm{NH}_{2}\right)_{2} \mathrm{PbBr}_{3}$, prepared when a stoichiometric mixture of DMF and DMSO solvents was used for the deposition of $\mathrm{PbBr}_{2}$, displayed an outstanding $\mathrm{V}_{\mathrm{OC}}$ of $1470 \mathrm{mV}$ (Table 1), in agreement with our previous work. $^{[34]}$

SEM analysis reveals the formation of elongated $\mathrm{CH}\left(\mathrm{NH}_{2}\right)_{2} \mathrm{PbBr}_{3}$ structures (Figure 5a) from $\mathrm{PbBr}_{2}(\mathrm{DMF})$ solution, whereas smooth and uniform $\mathrm{CH}\left(\mathrm{NH}_{2}\right)_{2} \mathrm{PbBr}_{3}$ films (Figure 5b) were obtained from $\mathrm{PbBr}_{2}(\mathrm{DMF}+\mathrm{DMSO})$ solution. We further evaluated the role of solvent on the emission characteristics of $\mathrm{CH}\left(\mathrm{NH}_{2}\right)_{2} \mathrm{PbBr}_{3}$ films using room temperature CL. Well-formed $\mathrm{CH}\left(\mathrm{NH}_{2}\right)_{2} \mathrm{PbBr}_{3}$ crystals obtained when pure DMF was employed as a solvent, radiate quite strongly (Figure 5c). However, emission is more uniformly distributed in 


\section{WILEY-VCH}

smoother $\mathrm{CH}\left(\mathrm{NH}_{2}\right)_{2} \mathrm{PbBr}_{3}$ films (Figure 5d), which perhaps justifies the higher photovoltage obtained from the devices based on them. In addition, strong and narrow CL spectra around $2.28 \mathrm{eV}$ with a linewidth of $110 \mathrm{meV}$ are exhibited by both $\mathrm{CH}\left(\mathrm{NH}_{2}\right)_{2} \mathrm{PbBr}_{3}$ films (Figure 5e,f). The emission is slightly red-shifted as compared to those of $\mathrm{CH}_{3} \mathrm{NH}_{3} \mathrm{PbBr}_{3}$, thus corroborating with their different band gaps. ${ }^{[39]}$
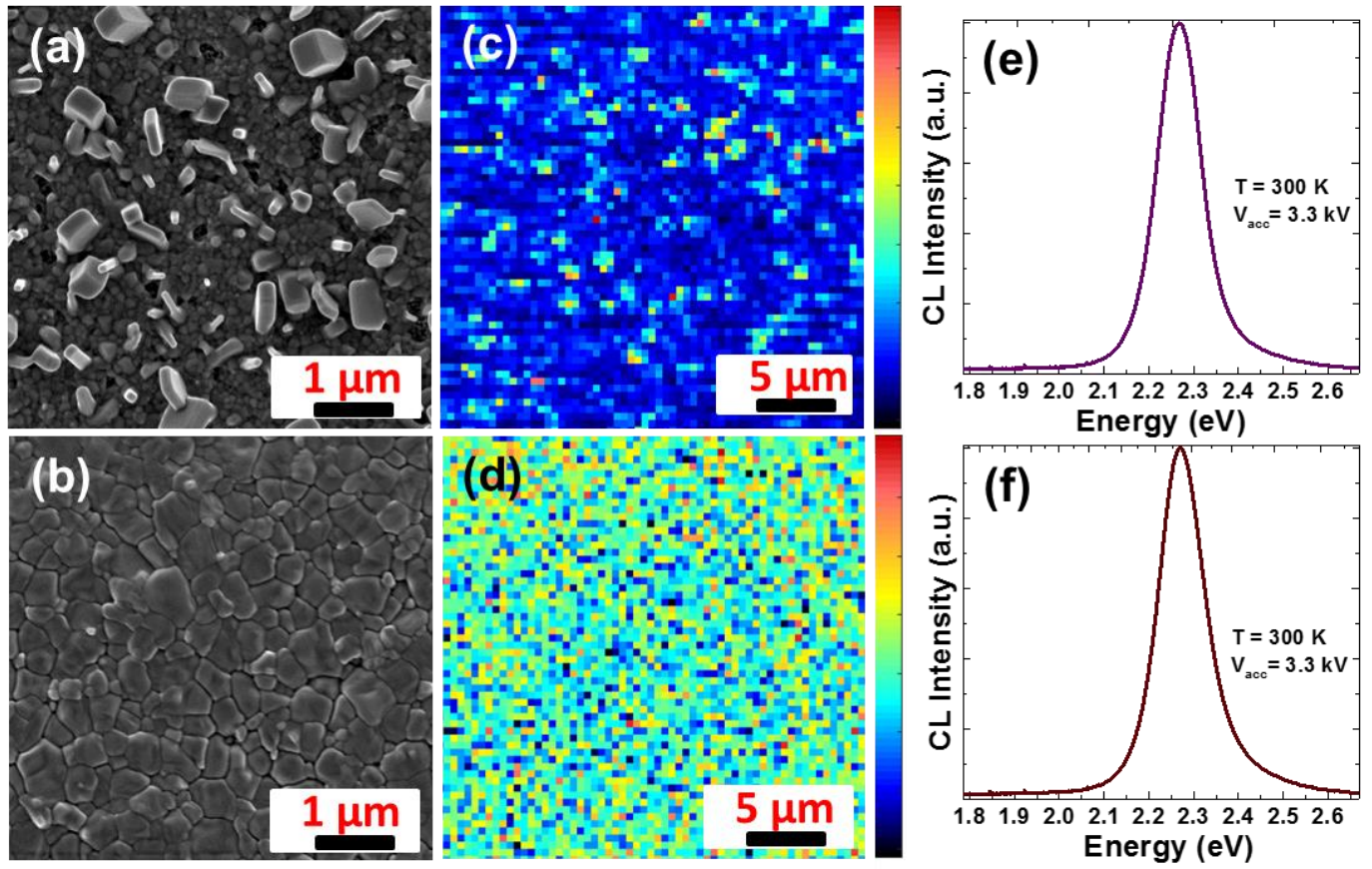

Figure 5. Morphological and cathodoluminescence studies of $\mathrm{CH}\left(\mathrm{NH}_{2}\right)_{2} \mathrm{PbBr}_{3}$ films involving a single or a mixture of solvents (a) SEM image of $\mathrm{CH}\left(\mathrm{NH}_{2}\right)_{2} \mathrm{PbBr}_{3}$ film involving DMF solvent. (b) SEM image of $\mathrm{CH}\left(\mathrm{NH}_{2}\right)_{2} \mathrm{PbBr}_{3}$ film involving a mixture of solvents (DMF and DMSO). (c) cathodoluminescence mapping acquired at $300 \mathrm{~K}$ on $\mathrm{CH}\left(\mathrm{NH}_{2}\right)_{2} \mathrm{PbBr}_{3}$ film involving DMF solvent. (d) cathodoluminescence mapping acquired at $300 \mathrm{~K}$ on $\mathrm{CH}\left(\mathrm{NH}_{2}\right)_{2} \mathrm{PbBr}_{3}$ film involving a mixture of solvents (DMF and DMSO). (e) cathodoluminescence spectrum obtained from $\mathrm{CH}\left(\mathrm{NH}_{2}\right)_{2} \mathrm{PbBr}_{3}$ film involving DMF solvent acquired at $300 \mathrm{~K}$ and (f) cathodoluminescence spectrum obtained from $\mathrm{CH}\left(\mathrm{NH}_{2}\right)_{2} \mathrm{PbBr}_{3}$ film involving a mixture of solvents (DMF and DMSO) acquired at $300 \mathrm{~K}$. (cathodoluminescence intensity scale bar is from 0.1 to 1 ) 


\section{WILEY-VCH}

\subsubsection{Structural characterization}

$\mathrm{CH}\left(\mathrm{NH}_{2}\right)_{2} \mathrm{PbBr}_{3}$ crystallizes in a pseudocubic phase $(\mathrm{Pm} 3 \mathrm{~m})$ at room temperature. ${ }^{[39]}$ Due to the relatively larger size of $\mathrm{CH}\left(\mathrm{NH}_{2}\right)_{2}{ }^{+}$as compared to $\left(\mathrm{CH}_{3}\right) \mathrm{NH}_{3}{ }^{+}$, spacing between the $\mathrm{PbBr}_{6}$ octahedra expands, which eventually increases the lattice constant of $\mathrm{CH}\left(\mathrm{NH}_{2}\right)_{2} \mathrm{PbBr}_{3}$.
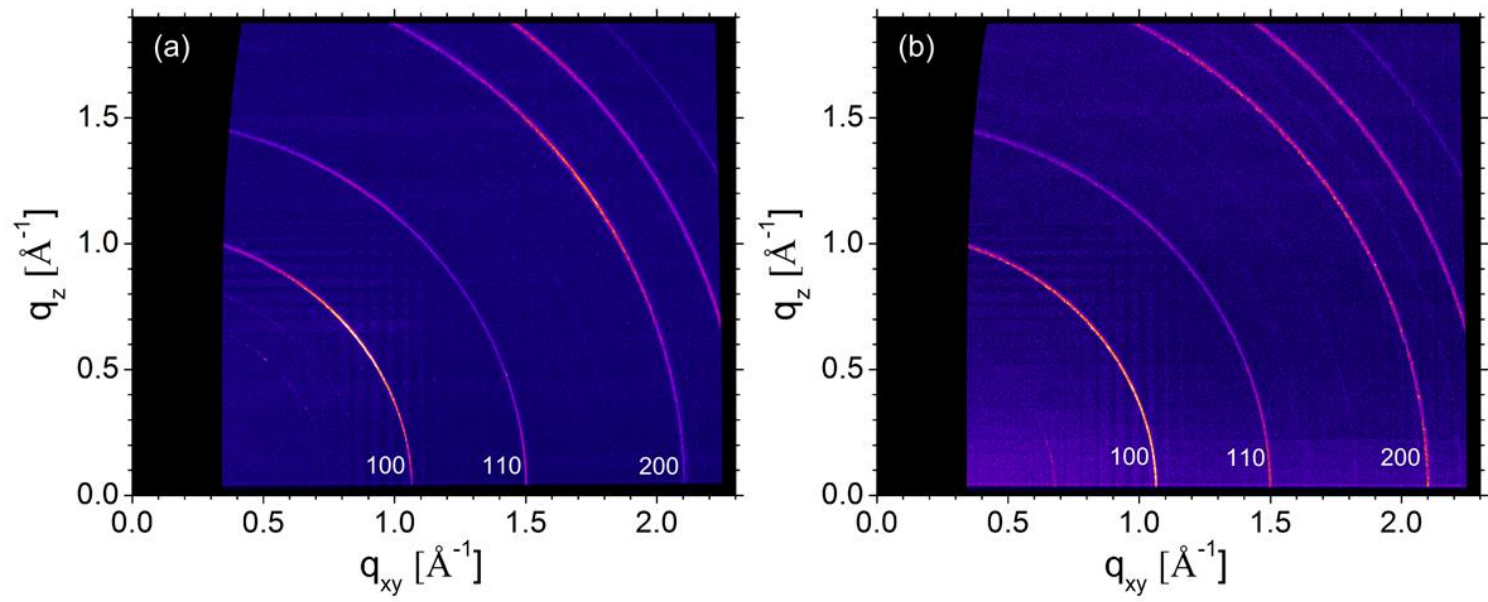

Figure 6. Reciprocal space maps from $\mathrm{CH}\left(\mathrm{NH}_{2}\right)_{2} \mathrm{PbBr}_{3}$ films obtained from a single or a mixture of solvents: (a) with single solvent (DMF) and (b) with solvent mixture (DMF+DMSO).

The reciprocal space maps of $\mathrm{CH}\left(\mathrm{NH}_{2}\right)_{2} \mathrm{PbBr}_{3}$ films (Figure 6) prepared by different solvents exhibit a diffraction pattern corresponding to the cubic structure with randomly oriented crystallites. ${ }^{[34]}$ Line scans at $\mathrm{q}_{\mathrm{z}} \approx 0 \AA^{-1}$ of both samples reveal that Bragg peak positions as well as peak intensities and widths coincide perfectly (Figure S8). With a single solvent (DMF), the crystallites have a preferred orientation with the [1-11] direction perpendicular to the substrate plane. This can be demonstrated from the angular intensity distributions of the diffraction rings (Figure S9). This orientation is similar as for $\mathrm{CH}_{3} \mathrm{NH}_{3} \mathrm{PbI}_{3}$ sketched in Figure 2d with alternating layers of $\mathrm{Pb}$ and $\mathrm{Br}$. Using a mixture of solvents (DMF + DMSO) for the preparation of $\mathrm{CH}\left(\mathrm{NH}_{2}\right)_{2} \mathrm{PbBr}_{3}$ films, the preferred crystal orientation vanishes and we obtain a nearly isotropic angular distribution (Figure S9). ${ }^{[40]}$ From CL analysis, we conclude that the smooth $\mathrm{CH}\left(\mathrm{NH}_{2}\right)_{2} \mathrm{PbBr}_{3}$ films shows isotropic distribution of cathodoluminescence, whereas large and oriented $\mathrm{CH}\left(\mathrm{NH}_{2}\right)_{2} \mathrm{PbBr}_{3}$ crystals 


\section{WILEY-VCH}

exhibit highly non-uniform emission. Such variations in the photophysical properties establish that the nature of the solvent employed for the deposition of the perovskite films is an important parameter. Overall, the favorable structural, morphological and emission features of the $\mathrm{CH}\left(\mathrm{NH}_{2}\right)_{2} \mathrm{PbBr}_{3}$ film considerably improve the photovoltage of the resulting devices.

\section{Conclusion}

A comprehensive study based on X-ray scattering and cathodoluminescence was carried out on $\mathrm{CH}_{3} \mathrm{NH}_{3} \mathrm{PbI}_{3}, \mathrm{CH}_{3} \mathrm{NH}_{3} \mathrm{PbBr}_{3}$ and $\mathrm{CH}\left(\mathrm{NH}_{2}\right)_{2} \mathrm{PbBr}_{3}$ perovskite films deposited using solution based approaches. The local emission characteristics of the various perovskite films explain the higher photovoltage yielded by the relatively better performing devices. Formation of $\mathrm{CH}_{3} \mathrm{NH}_{3} \mathrm{PbI}_{3}$ structures exhibiting a preferred orientation with the (202) plane aligned perpendicularly to the surface plane was realized when spin coating of $\mathrm{CH}_{3} \mathrm{NH}_{3} \mathrm{I}$ was adopted whereas, the dip-coated film is composed of randomly orientated $\mathrm{CH}_{3} \mathrm{NH}_{3} \mathrm{PbI}_{3}$ crystallites. From the comparative photovoltaic studies, we noticed that the preferred orientation of $\mathrm{CH}_{3} \mathrm{NH}_{3} \mathrm{PbI}_{3}$ crystallites is beneficial for the device performance as the $\mathrm{V}_{\mathrm{OC}}$ increased by $42 \mathrm{mV}$. While the crystal quality (in terms of structure) of $\mathrm{CH}_{3} \mathrm{NH}_{3} \mathrm{PbBr}_{3}$ is drastically decreased in the presence of $\mathrm{HBr}$, the photovoltage enhancement from 1.1 to1.46 $\mathrm{V}$ arises largely from the morphological improvements, i.e. a better connection between the crystallites owing to higher nucleation density. In the absence of $\mathrm{HBr}$, the domain size of $\mathrm{CH}_{3} \mathrm{NH}_{3} \mathrm{PbBr}_{3}$ structures becomes too large which results in disconnected domains and a nonuniform film. Apparently, both factors are detrimental to the device performance. In case of $\mathrm{CH}\left(\mathrm{NH}_{2}\right)_{2} \mathrm{PbBr}_{3}$, the smooth films display relatively a uniform cathodoluminescence and a $\mathrm{V}_{\mathrm{OC}}$ as high as $1.47 \mathrm{~V}$, whereas the randomly oriented $\mathrm{CH}\left(\mathrm{NH}_{2}\right)_{2} \mathrm{PbBr}_{3}$ crystal formation led to the highly asymmetric CL emission and a $\mathrm{V}_{\mathrm{OC}}$ of $1.1 \mathrm{~V}$. In addition, the mixed solvent changes both orientation as well as domain size of $\mathrm{CH}\left(\mathrm{NH}_{2}\right)_{2} \mathrm{PbBr}_{3}$ structures. We believe that the fundamental insights gained through our detailed studies will contribute towards further understanding of the hybrid perovskite materials. 


\section{WILEY-VCH}

\section{Experimental Section}

Materials: All solvents and lead halides salts were purchased from Sigma-Aldrich, and organic cation salts were purchased from Dyesol. All chemicals and solvents were used as received.

Photoanode preparation and device fabrication: The FTO (NSG 10, Nippon sheet glass, Japan) substrate was cleaned with a detergent, rinsed with de-ionized water and ethanol, and then treated with a $\mathrm{UV} / \mathrm{O}_{3}$ cleaner for $15 \mathrm{~min}$. The aerosol spray pyrolysis was employed to deposit $30 \mathrm{~nm}$-thick $\mathrm{TiO}_{2}$ compact layer on the substrates at $450{ }^{\circ} \mathrm{C}$ using a commercial titanium diisopropoxide bis(acetylacetonate) solution (75\% in 2-propanol, Sigma-Aldrich) diluted in ethanol (Sigma-Aldrich) (1:9, volume ratio) as precursor and oxygen as a carrier gas. The $\mathrm{TiO}_{2}$ commercial paste (Dyesol 30NRD) was spin-coated onto a FTO glass containing spray deposited $\mathrm{TiO}_{2}$ compact layer. After sintering through a series steps $\left(325^{\circ} \mathrm{C}\right.$ for 5 min with $15 \mathrm{~min}$ ramp time, $375{ }^{\circ} \mathrm{C}$ for $5 \mathrm{~min}$ with $5 \mathrm{~min}$ ramp time, $450{ }^{\circ} \mathrm{C}$ for $15 \mathrm{~min}$ with $5 \mathrm{~min}$ ramp time, and $500{ }^{\circ} \mathrm{C}$ for $15 \mathrm{~min}$ with $5 \mathrm{~min}$ ramp time), the sintered mesoporous $\mathrm{TiO}_{2}$ films were used as photoanodes.

Deposition of $\mathrm{CH}_{3} \mathrm{NH}_{3} \mathrm{PbI}_{3}$ using sequential method: $1.2 \mathrm{M}$ solutions of $\mathrm{PbI}_{2}$ (99\%, Aldrich) was prepared in $\mathrm{N}, \mathrm{N}$-dimethylformamide (DMF, Sigma Aldrich) solvent by constant stirring at $100{ }^{\circ} \mathrm{C}$ for 15 minutes. The $\mathrm{TiO}_{2}$ photoanode films were then coated with $\mathrm{PbI}_{2}$ by spincoating at $6500 \mathrm{rpm}$ for $30 \mathrm{~s}$, and dried at $80^{\circ} \mathrm{C}$ for $15 \mathrm{~min}$. After cooling to room temperature, $200 \mu \mathrm{L}$ solution of $\mathrm{CH}_{3} \mathrm{NH}_{3} \mathrm{I}$ in 2-propanol $\left(8 \mathrm{mg} \mathrm{mL}^{-1}\right)$ was spin coated on the resulting $\mathrm{PbI}_{2}$ films with a delay of $120 \mathrm{~s}$ for $30 \mathrm{~s}$, and were dried at $80{ }^{\circ} \mathrm{C}$ for $15 \mathrm{~min}$. Additionally, instead of spin coating $\mathrm{CH}_{3} \mathrm{NH}_{3} \mathrm{I}$ in 2-propanol solution, $\mathrm{PbI}_{2}$ films were dipped into a solution of

$\mathrm{CH}_{3} \mathrm{NH}_{3} \mathrm{I}$ in 2-propanol $\left(8 \mathrm{mg} \mathrm{mL}^{-1}\right)$ for 30 seconds, and were dried at $80{ }^{\circ} \mathrm{C}$ for $15 \mathrm{~min}$. Deposition of $\mathrm{CH}_{3} \mathrm{NH}_{3} \mathrm{PbBr}_{3}$ using single-step method: One mole of each $\mathrm{PbBr}_{2}$ and $\mathrm{CH}_{3} \mathrm{NH}_{3} \mathrm{Br}$ were dissolved in $1 \mathrm{~mL}$ of $\mathrm{N}, \mathrm{N}$-dimethylformamide solvent. After heating at $80^{\circ} \mathrm{C}$ for $2 \mathrm{~min}$, the reaction mixture was deposited onto $\mathrm{TiO}_{2}$ photoanode films by spin-coating at 


\section{WILEY-VCH}

$3000 \mathrm{rpm}$ for $30 \mathrm{~s}$, and the resulting films were annealed at $110^{\circ} \mathrm{C}$ for $15 \mathrm{~min} .10 \%$ by volume of $\mathrm{HBr}$ solution was added to the perovskite precursor solution to obtain $\mathrm{CH}_{3} \mathrm{NH}_{3} \mathrm{PbBr}_{3}$ films . Deposition of $\mathrm{CH}\left(\mathrm{NH}_{2}\right)_{2} \mathrm{PbBr}_{3}$ perovskites using sequential method: $1.2 \mathrm{M} \mathrm{PbBr}_{2}$ precursor solutions were prepared in DMF and DMSO by constant stirring at $60{ }^{\circ} \mathrm{C}$ for $30 \mathrm{~min} . \mathrm{PbBr}_{2}$ (DMF), and $\mathrm{PbBr}_{2}$ (DMF+DMSO in 1:1 volume ratio) solutions were spin coated onto the mesoporous $\mathrm{TiO}_{2}$ films at $3000 \mathrm{rpm}$ for $30 \mathrm{~s}$. After annealing the films at $80{ }^{\circ} \mathrm{C}$ for $15 \mathrm{~min}$, the cooled films were dipped into isopropanol solution of $\mathrm{CH}\left(\mathrm{NH}_{2}\right)_{2} \mathrm{Br}(50 \mathrm{mM})$ for $5 \mathrm{~min}$ at $60{ }^{\circ} \mathrm{C}$, and dried at $80{ }^{\circ} \mathrm{C}$ for $30 \mathrm{~min}$.

Deposition of spiro-OMeTAD: The spiro-OMeTAD was deposited by spin-coating (4000 rpm, $30 \mathrm{~s}) 40 \mu \mathrm{L}$ of solution prepared by dissolving $72.3 \mathrm{mg}\left(2,2^{\prime}, 7,7^{\prime}\right.$-tetrakis $(N, N$-di- $p$ methoxyphenylamine)-9,9-spirobifluorene) (spiro-OMeTAD), $17.5 \mu \mathrm{L}$ of a stock solution of $520 \mathrm{mg} \mathrm{ml}^{-1}$ bis(trifluoromethylsulphonyl)imide lithium-salt in acetonitrile, and $29 \mu \mathrm{L}$ of a stock solution of $300 \mathrm{mg} \mathrm{mL}^{-1}$ tris(2-(1H-pyrazol-1-yl)-4-tert-butylpyridine)cobalt(III) in acetonitrile, and $28.8 \mu \mathrm{L}$ 4-tert-butylpyridine in $1 \mathrm{~mL}$ chlorobenzene. The device fabrication was carried out under controlled atmospheric conditions with humidity $<1 \%$ and was finally completed by thermally evaporating $70 \mathrm{~nm}$ gold layer as a back contact.

Materials characterization: A field-emission scanning electron microscope (FESEM, Merlin) was used to examine the morphology of the perovskite samples. An electron beam accelerated to $3 \mathrm{kV}$ was used with an in-lens detector.

Structural characterization: X-ray scattering experiments were performed at the Swiss Light Source at the X04SA MS-Surf-Diffr beamline with a photon energy of $14 \mathrm{keV} .{ }^{[41]}$ The reciprocal space maps (RSM) were measured under grazing incidence geometry with an angle of incidence of $0.15^{\circ}$. Each RSM is assembled from $31 * 31$ small images measured subsequently with a PILATUS area detector at a sample-detector distance of $1340 \mathrm{~mm}$. During the measurement the samples were kept under vacuum. 


\section{WILEY-VCH}

Photovoltaic characterization: A $450 \mathrm{~W}$ xenon lamp (Oriel, USA) was used as the light source for photovoltaic $(J-V)$ measurements. The spectral output of the lamp was filtered using a Schott K113 Tempax sunlight filter (Präzisions Glas \& Optik GmbH, Germany) to reduce the mismatch between the simulated and actual solar spectrum to less than $2 \%$. The current-voltage (J-V) characteristics of the devices were recorded with a Keithley model 2400 digital source meter (Keithley, USA). The photo-active area of $0.16 \mathrm{~cm}^{2}$ was defined using a dark-coloured metal mask. All the $(J-V)$ measurements were carried out at a scan speed of $0.02 \mathrm{~V} / \mathrm{s}$.

Cathodoluminescence: Cathodoluminescence spectroscopy measurements were performed using an Attolight Alalin Chronos 4027 system, working in continuous operation mode. A probe current of $2 \mathrm{nA}$ and acceleration voltage of $3.3 \mathrm{kV}$ has been selected as a result of tradeoff between spatial resolution and CL signal intensity. The dwell time of $50 \mathrm{~ms}$ at $300 \mathrm{~K}$ was chosen for acquiring the data.

\section{Supporting Information}

Current-voltage characteristics of difference devices, and XRD, SEM and cathodoluminescence data obtained from different perovskite films. Supporting Information is available from the Wiley Online Library or from the author.

\section{Acknowledgements}

M.I.D, S.M.Z and M.G. thank the King Abdulaziz City for Science and Technology (KACST) and Swiss National Science Foundation (SNSF) for financial support. M. I. D., S. M. Z. and M. G. thank funding from the European Union's Horizon 2020 programme, through a FET Open research and innovation action under grantagreement No. 687008. G.J. acknowledges financial support from the Swiss National Science Foundation under project no. 154853. We acknowledge the Paul Scherrer Institut, Villigen, Switzerland for provision of synchrotron radiation at beamline X04SA of the SLS and would like to thank N. Casati and P. Willmott for technical assistance.

Received: ((will be filled in by the editorial staff))

Revised: ((will be filled in by the editorial staff)) Published online: ((will be filled in by the editorial staff)) 


\section{WILEY-VCH}

References

[1] B. Saparov, D. B. Mitzi, Chem. Rev. 2016, 116, 4558-4596.

[2] J. Burschka, N. Pellet, S.-J. Moon, R. Humphry-Baker, P. Gao, M. K. Nazeeruddin, M. Gratzel, Nature 2013, 499, 316-319.

[3] D. Bi, W. Tress, M. I. Dar, P. Gao, J. Luo, C. Renevier, K. Schenk, A. Abate, F.

Giordano, J.-P. Correa Baena, J.-D. Decoppet, S. M. Zakeeruddin, M. K. Nazeeruddin, M.

Grätzel, A. Hagfeldt, Sci. Adv. 2016, 2, e1501170.

[4] W.-J. Yin, T. Shi, Y. Yan, Adv. Mater. 2014, 26, 4653-4658.

[5] J.-H. Im, I.-H. Jang, N. Pellet, M. Grätzel, N.-G. Park, Nat Nano 2014, 9, 927-932.

[6] M. I. Saidaminov, A. L. Abdelhady, B. Murali, E. Alarousu, V. M. Burlakov, W.

Peng, I. Dursun, L. Wang, Y. He, G. Maculan, A. Goriely, T. Wu, O. F. Mohammed, O. M. Bakr, Nat. Commun. 2015, 6, 7586.

[7] H. L. Sullivan, H. Louis The tall office building artistically considered. Lippincott's Magazine, March 1896

[8] N. J. Jeon, J. H. Noh, Y. C. Kim, W. S. Yang, S. Ryu, S. I. Seok, Nat Mater 2014, 13, 897-903.

[9] M. I. Dar, N. Arora, P. Gao, S. Ahmad, M. Grätzel, M. K. Nazeeruddin, Nano Lett. 2014, 14, 6991-6996.

[10] N. J. Jeon, J. H. Noh, W. S. Yang, Y. C. Kim, S. Ryu, J. Seo, S. I. Seok, . Nature 2015, $517,476-480$. 


\section{WILEY-VCH}

[11] M. M. Lee, J. Teuscher, T. Miyasaka, T. N. Murakami, H. J. Snaith, Science 2012, 338, 643-647.

[12] M. Ibrahim Dar, M. Abdi-Jalebi, N. Arora, T. Moehl, M. Grätzel, M. K. Nazeeruddin, Adv. Mater. 2015, 27, 7221-7228.

[13] M. I. Dar, M. Abdi-Jalebi, N. Arora, M. Grätzel, M. K. Nazeeruddin, Adv. Energy

Mater. 2016, 6, 1501358

[14] W. Zhang, M. Saliba, D. T. Moore, S. K. Pathak, M. T. Hörantner, T. Stergiopoulos, S.

D. Stranks, G. E. Eperon, J. A. Alexander-Webber, A. Abate, A. Sadhanala, S. Yao, Y. Chen, R. H. Friend, L. A. Estroff, U. Wiesner, H. J. Snaith, Nat. Commun. 2015, 6, 6142.

[15] J. Schlipf, P. Docampo, C. J. Schaffer, V. Körstgens, L. Bießmann, F. Hanusch, N. Giesbrecht, S. Bernstorff, T. Bein, P. Müller-Buschbaum, J. Phys. Chem. Lett. 2015, 6, 12651269.

[16] T. Miyadera, Y. Shibata, T. Koganezawa, T. N. Murakami, T. Sugita, N. Tanigaki, M. Chikamatsu, Nano Lett. 2015, 15, 5630-5634.

[17] B. Yang, J. Keum, O. S. Ovchinnikova, A. Belianinov, S. Chen, M.-H. Du, I. N.

Ivanov, C. M. Rouleau, D. B. Geohegan, K. Xiao, J. Am. Chem. Soc.2016, 138, 5028-5035.

[18] A. T. Barrows, S. Lilliu, A. J. Pearson, D. Babonneau, A. D. F. Dunbar, D. G. Lidzey, Adv. Funct. Mater. 2016, 26, 4934-4942.

[19] S. Lee, J. Feldman, S. S. Lee, Cryst. Growth Des. 2016, 16, 4744-4751.

[20] D. T. Moore, H. Sai, K. W. Tan, D.-M. Smilgies, W. Zhang, H. J. Snaith, U. Wiesner, L. A. Estroff, J. Am. Chem. Soc. 2015, 137, 2350-2358. 


\section{WILEY-VCH}

[21] A. Sharenko, M. F. Toney, J. Am. Chem. Soc. 2016, 138, 463-470.

[22] C. G. Bischak, E. M. Sanehira, J. T. Precht, J. M. Luther, N. S. Ginsberg, Nano Lett. 2015, 15, 4799-4807.

[23] H.-S. Kim, C.-R. Lee, J.-H. Im, K.-B. Lee, T. Moehl, A. Marchioro, S.-J. Moon, R.

Humphry-Baker, J.-H. Yum, J. E. Moser, M. Grätzel, N.-G. Park, Sci. Rep. 2012, 2, 591.

[24] O. Hentz, Z. Zhao, S. Gradečak, Nano Lett. 2016, 16, 1485-1490.

[25] M. I. Dar, G. Jacopin, M. Hezam, N. Arora, S. M. Zakeeruddin, B. Deveaud, M. K.

Nazeeruddin, M. Grätzel, ACS Photonics 2016, 3, 947-952.

[26] A. D. Wright, C. Verdi, R. L. Milot, G. E. Eperon, M. A. Pérez-Osorio, H. J. Snaith, F.

Giustino, M. B. Johnston, L. M. Herz, Nat Commun. 2016, 7, 11755.

[27] C. Xiao, Z. Li, H. Guthrey, J. Moseley, Y. Yang, S. Wozny, H. Moutinho, B. To, J. J.

Berry, B. Gorman, Y. Yan, K. Zhu, M. Al-Jassim, J. Phys. Chem. C 2015, 119, 26904-26911.

[28] N. Onoda-Yamamuro, T. Matsuo, H. Suga, J. Phys. Chem. Solids 1992, 53, 935-939.

[29] T. Baikie, Y. Fang, J. M. Kadro, M. Schreyer, F. Wei, S. G. Mhaisalkar, M. Graetzel,

T. J. White, J. Mater. Chem. A 2013, 1, 5628-5641.

[30] M. Schreier, L. Curvat, F. Giordano, L. Steier, A. Abate, S. M. Zakeeruddin, J. Luo, M.

T. Mayer, M. Grätzel, Nat Commun. 2015, 6, 7326.

[31] J. H. Heo, D. H. Song, S. H. Im, Adv. Mater. 2014, 26, 8179-8183.

[32] J. H. Noh, S. H. Im, J. H. Heo, T. N. Mandal, S. I. Seok, Nano Letters 2013, 13, 17641769. 


\section{WILEY-VCH}

[33] N. Onoda-Yamamuro, O. Yamamuro, T. Matsuo, H. Suga, J. Phys. Chem. Solid 1992, $53,277-281$.

[34] N. Arora, M. I. Dar, M. Hezam, W. Tress, G. Jacopin, T. Moehl, P. Gao, A. S.

Aldwayyan, B. Deveaud, M. Grätzel, M. K. Nazeeruddin Adv. Funct. Mater. 2016, 26, 28462854.

[35] Y. Wu, A. Islam, X. Yang, C. Qin, J. Liu, K. Zhang, W. Peng, L. Han, Energy Environ. Sci. 2014, 7, 2934-2938.

[36] W. S. Yang, J. H. Noh, N. J. Jeon, Y. C. Kim, S. Ryu, J. Seo, S. I. Seok, Science 2015, $348,1234-1237$.

[37] N. Ahn, D.-Y. Son, I.-H. Jang, S. M. Kang, M. Choi, N.-G. Park, J. Am. Chem. Soc. 2015, 137, 8696-8699.

[38] W. Li, J. Fan, J. Li, Y. Mai, L. Wang, J. Am. Chem. Soc. 2015, 137, 10399-10405.

[39] F. C. Hanusch, E. Wiesenmayer, E. Mankel, A. Binek, P. Angloher, C. Fraunhofer, N. Giesbrecht, J. M. Feckl, W. Jaegermann, D. Johrendt, T. Bein, P. Docampo, J. Phys. Chem. Lett. 2014, 5, 2791-2795.

[40] J. Cao, X. Jing, J. Yan, C. Hu, R. Chen, J. Yin, J. Li, N. Zheng, J. Am. Chem. Soc. 2016, 138, 9919-9926.

[41] P. R. Willmott, D. Meister, S. J. Leake, M. Lange, A. Bergamaschi, M. Boge, M.

Calvi, C. Cancellieri, N. Casati, A. Cervellino, Q. Chen, C. David, U. Flechsig, F. Gozzo, B. Henrich, S. Jaggi-Spielmann, B. Jakob, I. Kalichava, P. Karvinen, J. Krempasky, A. Ludeke, 


\section{WILEY-VCH}

R. Luscher, S. Maag, C. Quitmann, M. L. Reinle-Schmitt, T. Schmidt, B. Schmitt, A. Streun,

I. Vartiainen, M. Vitins, X. Wang, R. Wullschleger J. Synchrotron Rad. 2013, 20, 667-682. 


\section{WILEY-VCH}

The comparative analysis of the local structural, morphological, and emission characteristics of the different perovskite films rationally justifies the higher photovoltage yielded by the relatively better performing devices.

Keywords: Perovskite solar cells, Cathodoluminescence, Electron microscopy, X-ray scattering, Photovoltage

M. Ibrahim Dar, * Alexander Hinderhofer, Gwenole Jacopin, Valentina Belova, Neha Arora, Shaik Mohammed Zakeeruddin, Frank Schreiber, Michael Grätzel

Function Follows Form: Correlation Between the Growth and Local Emission of Perovskite Structures, and the Performance of Solar Cells

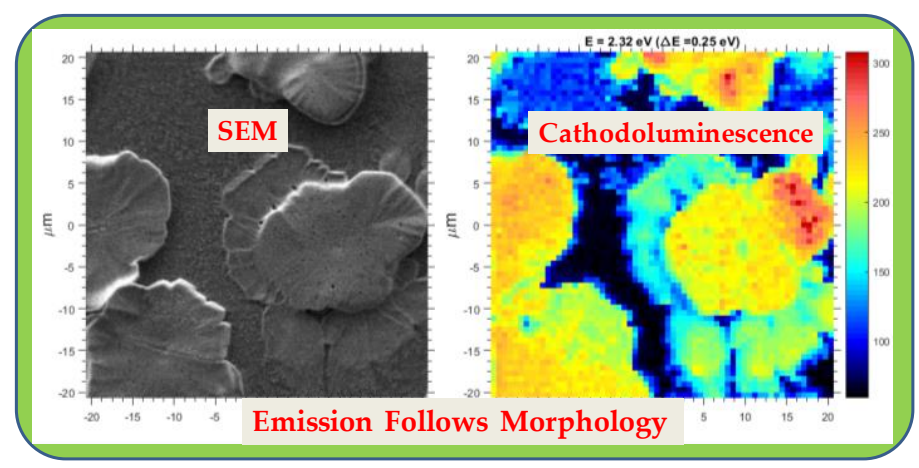




\section{WILEY-VCH}

Copyright WILEY-VCH Verlag GmbH \& Co. KGaA, 69469 Weinheim, Germany, 2016.

\section{Supporting Information}

Function Follows Form: Correlation Between the Growth and Local Emission of Perovskite Structures, and the Performance of Solar Cells

M. Ibrahim Dar, * Alexander Hinderhofer, Gwenole Jacopin, Valentina Belova, Neha Arora, Shaik Mohammed Zakeeruddin, Frank Schreiber, Michael Grätzel

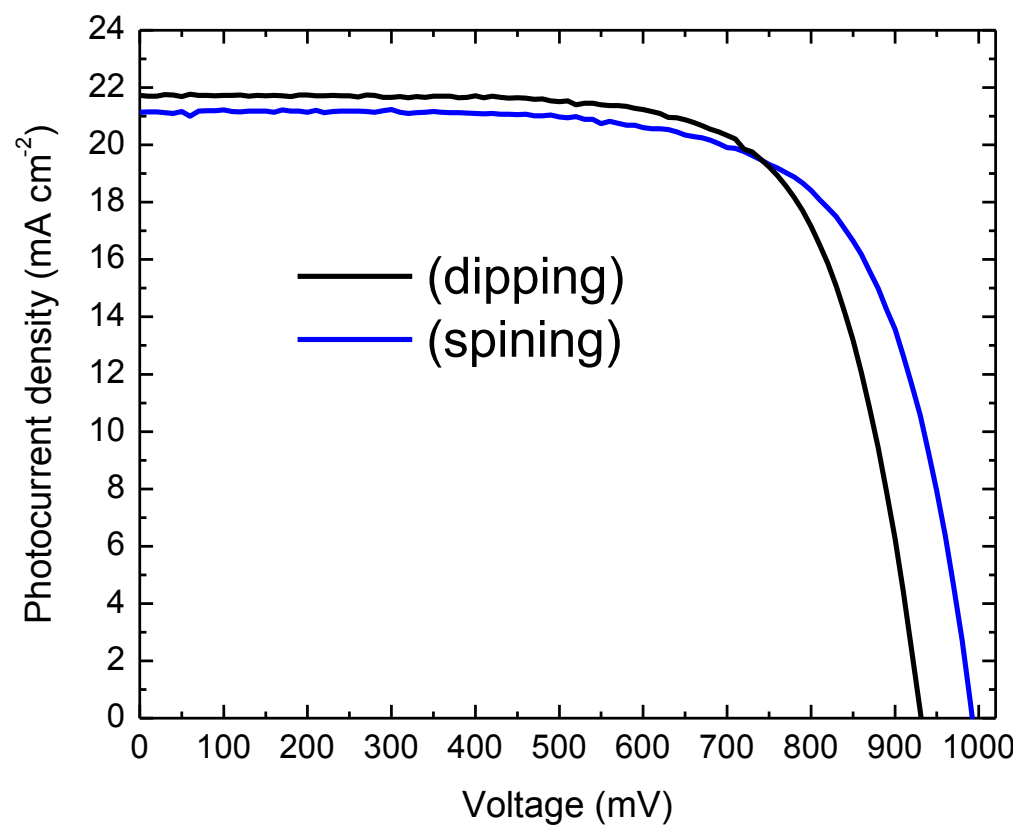

Figure S1. The current-voltage $(\mathrm{J}-\mathrm{V})$ curves of $\mathrm{CH}_{3} \mathrm{NH}_{3} \mathrm{PbI}_{3}$ devices recorded under AM 1.5 global illumination. 


\section{WILEY-VCH}

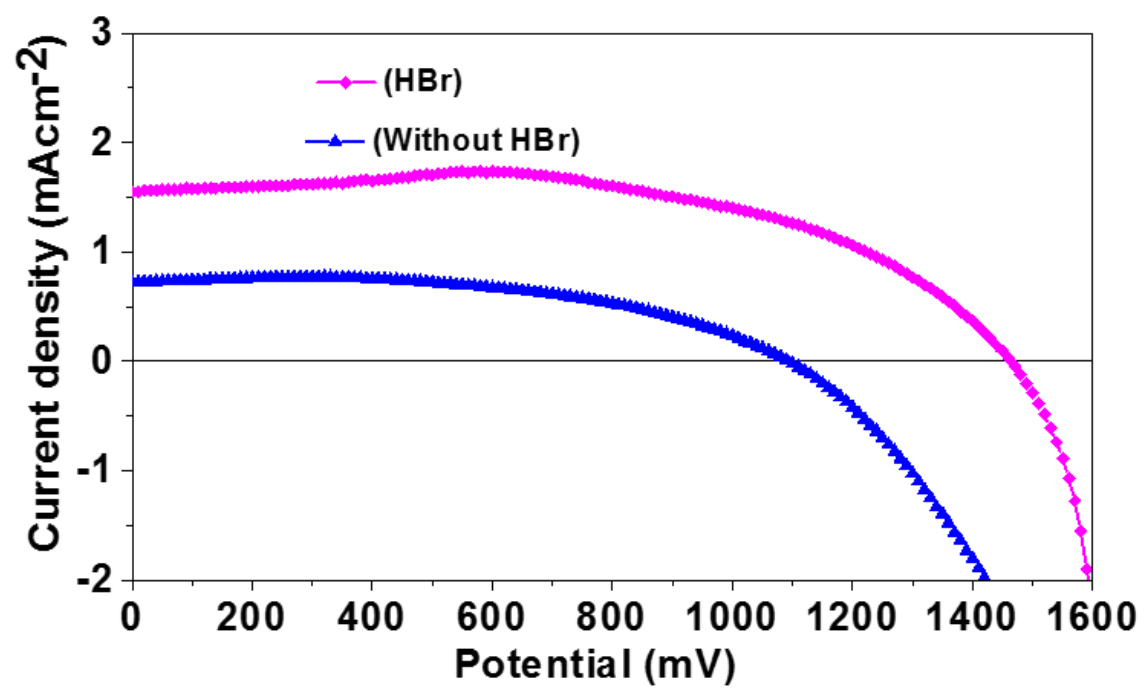

Figure S2. The current-voltage (J-V) curves of $\mathrm{CH}_{3} \mathrm{NH}_{3} \mathrm{PbBr}_{3}$ devices recorded under $\mathrm{AM}$ 1.5 global illumination.

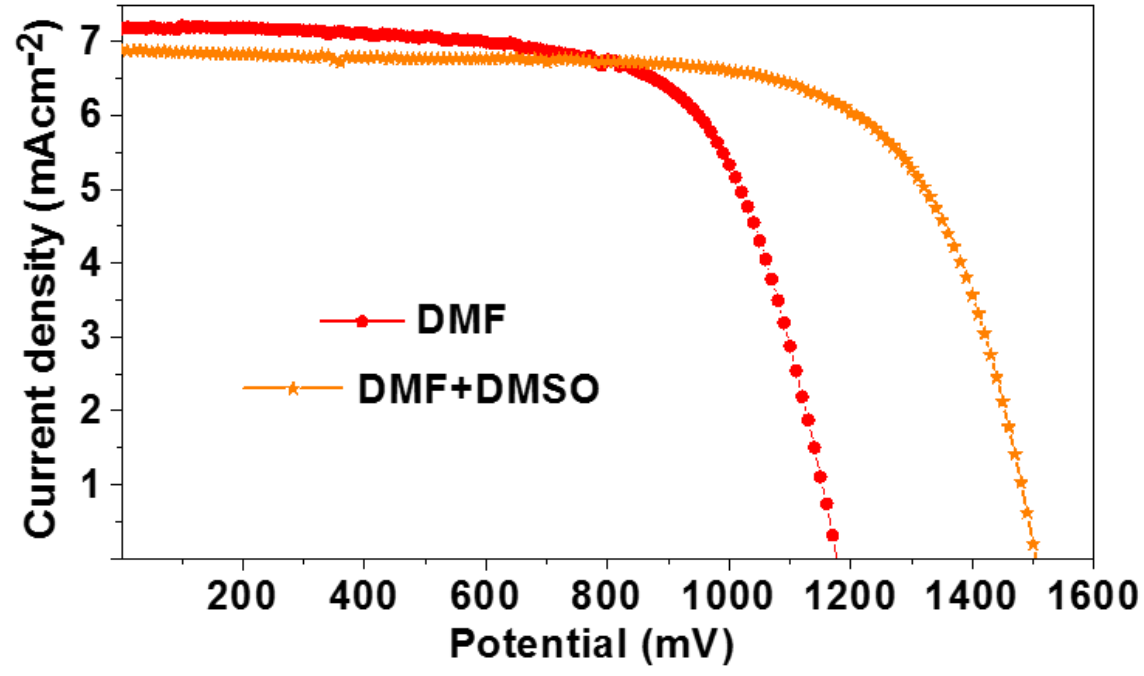

Figure S3. The current-voltage (J-V) curves of $\mathrm{CH}\left(\mathrm{NH}_{2}\right)_{2} \mathrm{PbBr}_{3}$ devices recorded under $\mathrm{AM}$ 1.5 global illumination. 


\section{WILEY-VCH}
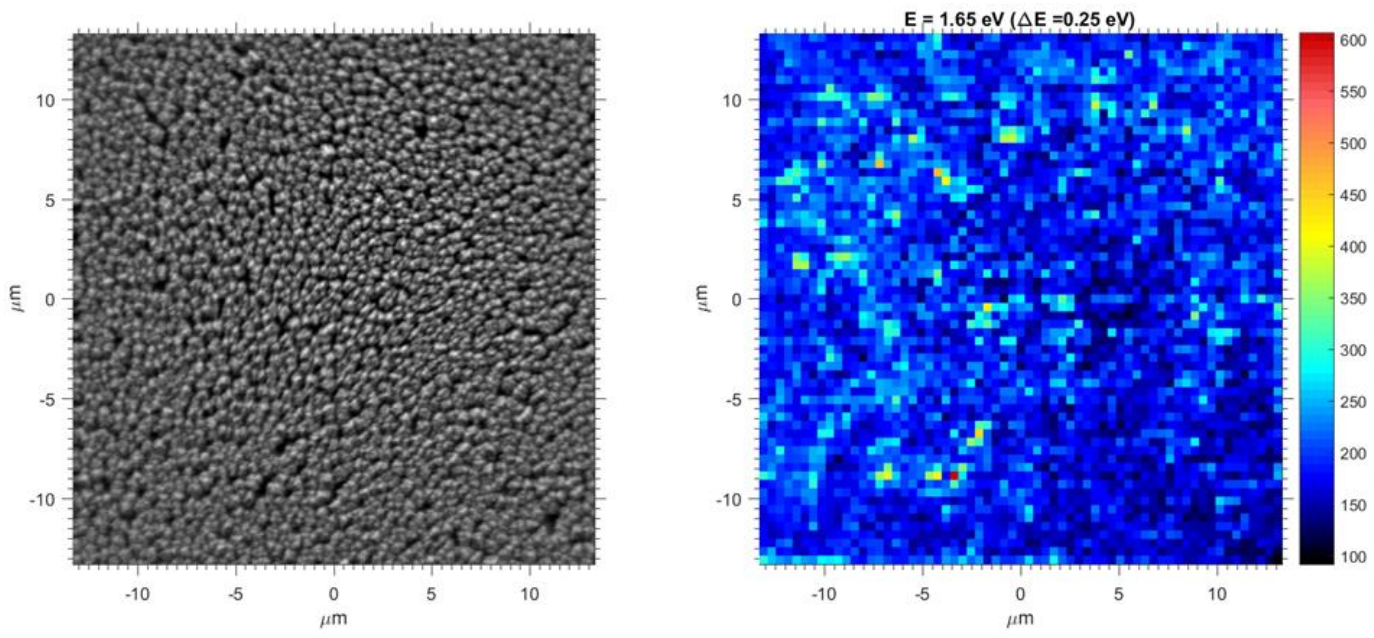

Figure S4. SEM micrograph (left side), and cathodoluminescence mapping (right side) acquired at $300 \mathrm{~K}$ from $\mathrm{CH}_{3} \mathrm{NH}_{3} \mathrm{PbI}_{3}$ film involving dipping.
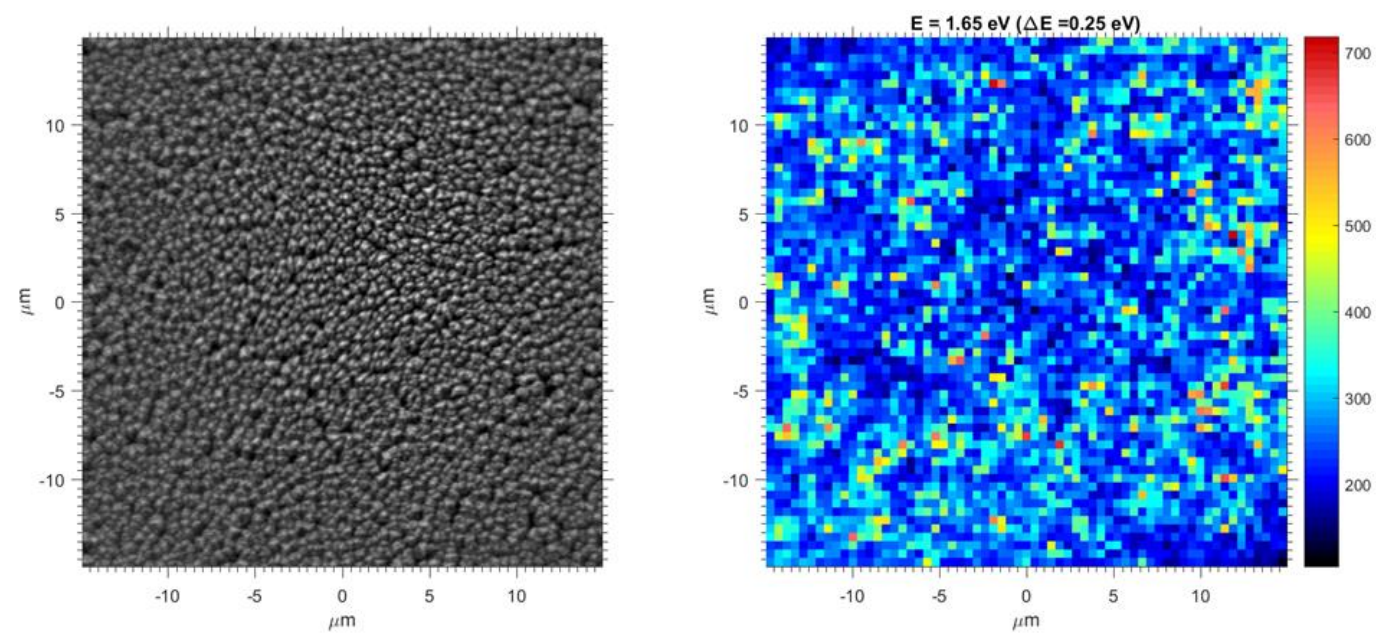

Figure S5. SEM micrograph (left side), and cathodoluminescence mapping (right side) acquired at $300 \mathrm{~K}$ from $\mathrm{CH}_{3} \mathrm{NH}_{3} \mathrm{PbI}_{3}$ film involving spin coating. 


\section{WILEY-VCH}

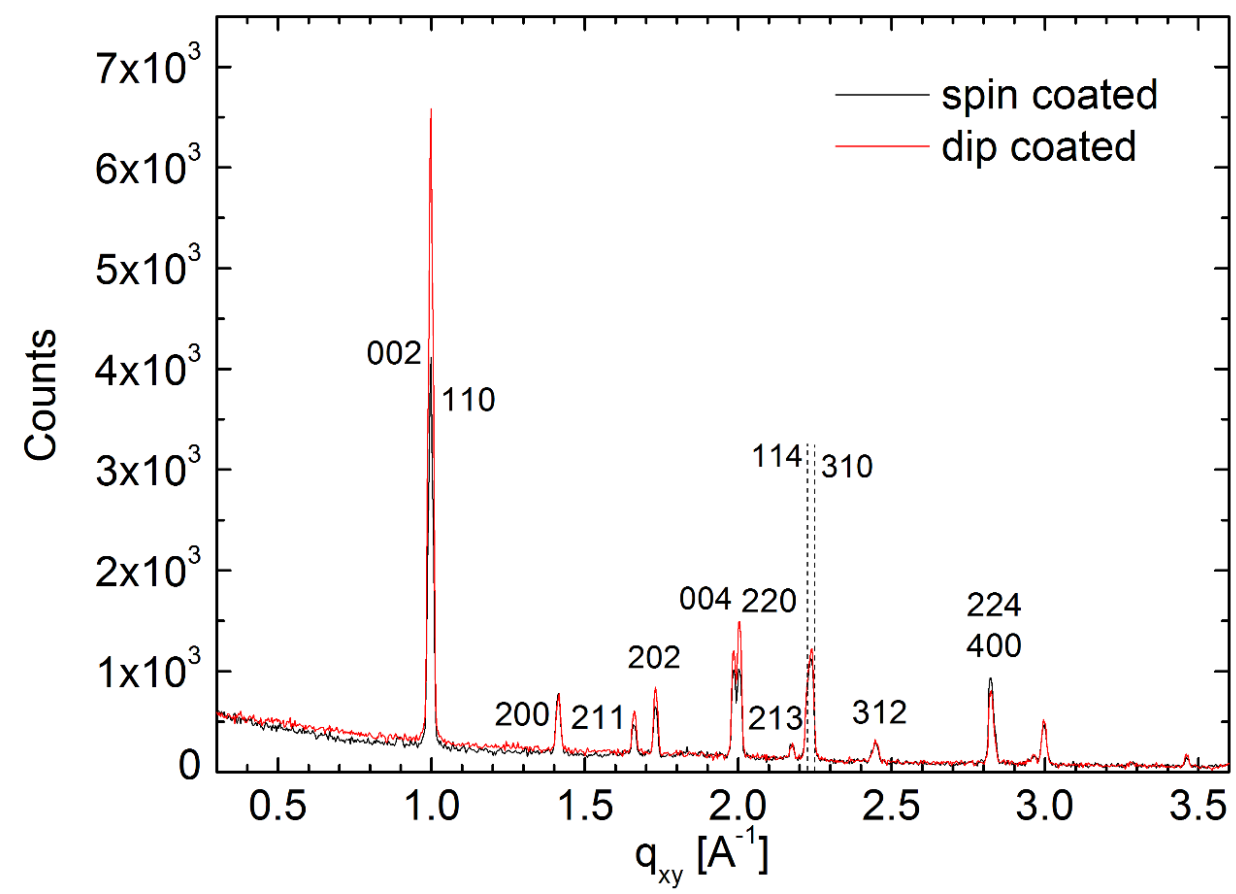

Figure S6. GIXD in-plane scan at $\mathrm{q}_{\mathrm{z}} \approx 0 \AA^{-1}$ from $\mathrm{CH}_{3} \mathrm{NH}_{3} \mathrm{PbI}_{3}$ involving spinning of MAI and dipping into MAI solution.
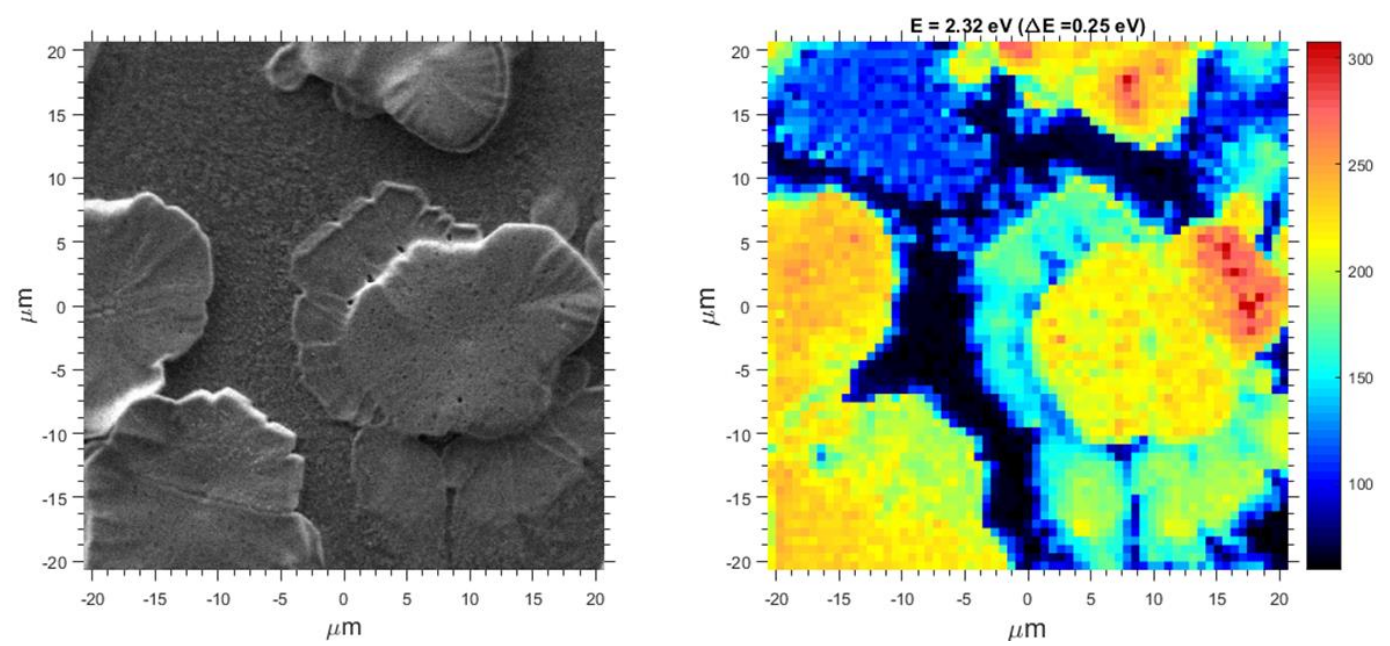

Figure S7. SEM micrograph (left side), and cathodoluminescence mapping (right side) acquired at $300 \mathrm{~K}$ on $\mathrm{CH}_{3} \mathrm{NH}_{3} \mathrm{PbBr}_{3}$ film (without $\mathrm{HBr}$ ). 


\section{WILEY-VCH}

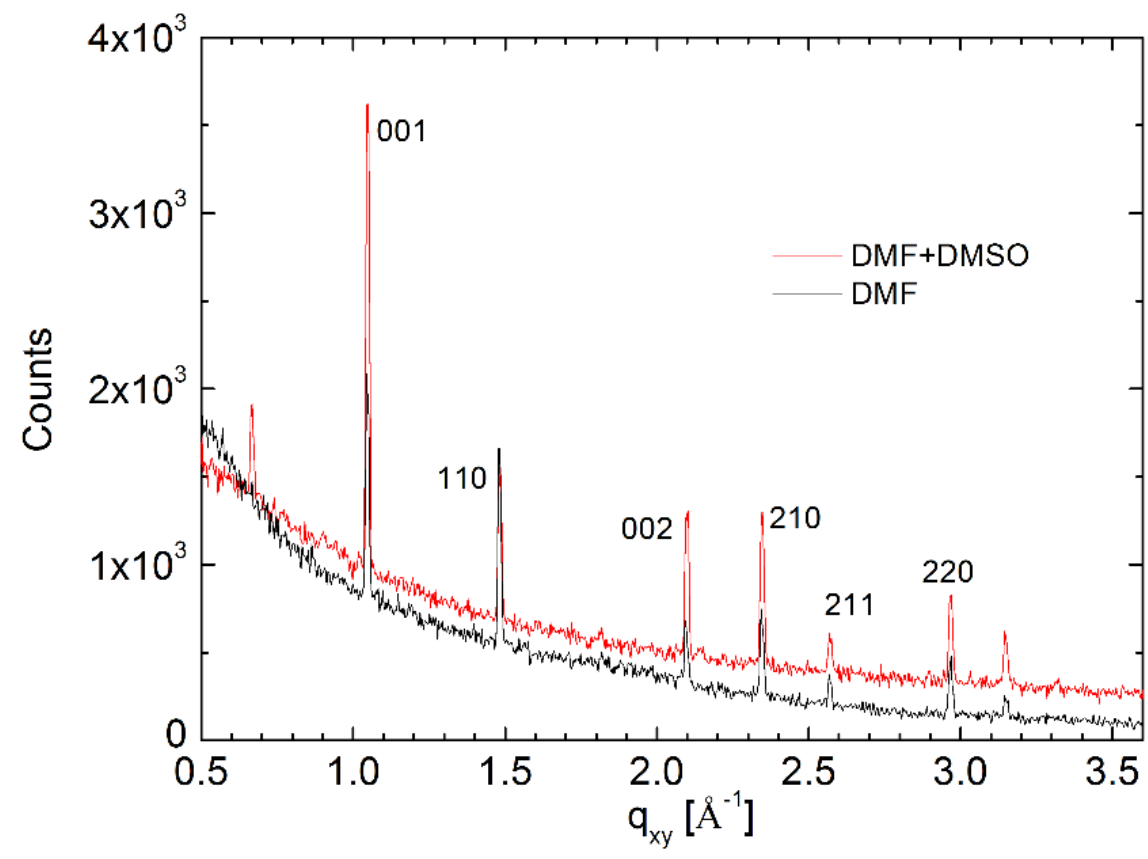

Figure S8. GIXD in-plane scan at $\mathrm{q}_{\mathrm{z}} \approx 0 \AA^{-1}$ from of $\mathrm{CH}\left(\mathrm{NH}_{2}\right)_{2} \mathrm{PbBr}_{3}$ prepared with a single solvent (DMF) and with solvent mixture (DMF+DMSO).

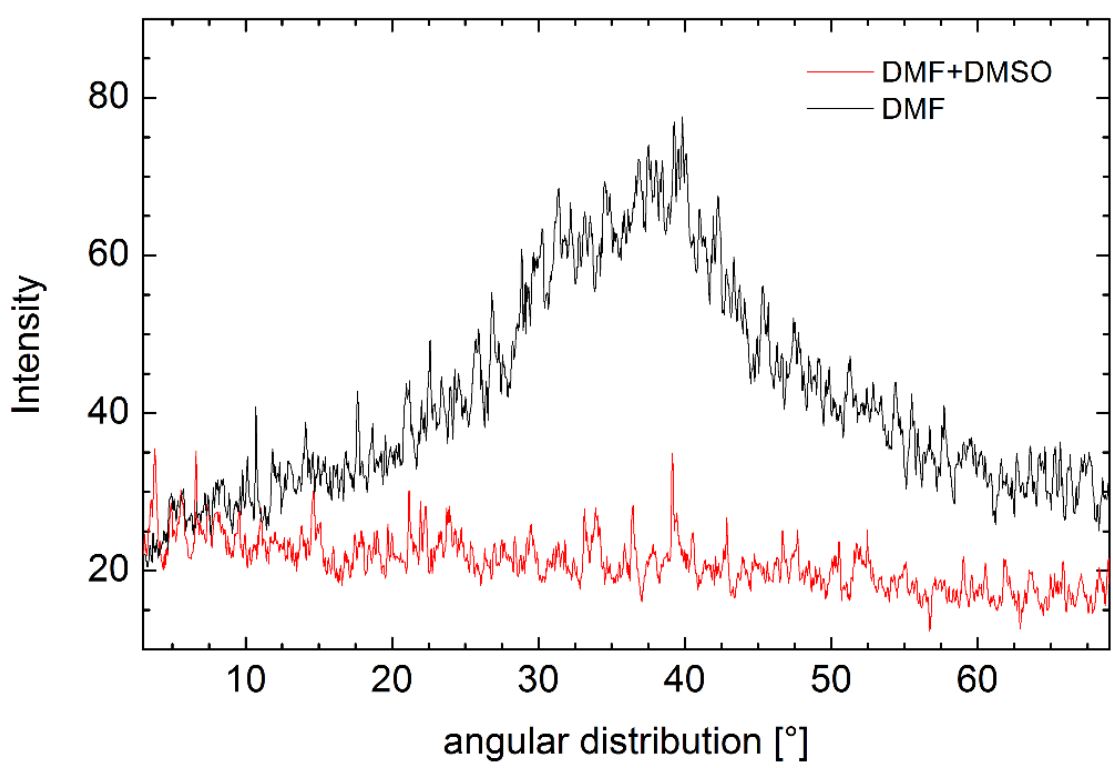

Figure S9. Angular intensity distribution of the 001 Bragg reflection of $\mathrm{CH}\left(\mathrm{NH}_{2}\right)_{2} \mathrm{PbBr}_{3}$ as extracted from Figure 6a and 6b. (a) with single solvent (DMF) (b) with solvent mixture (DMF+DMSO). 


\section{WILEY-VCH}

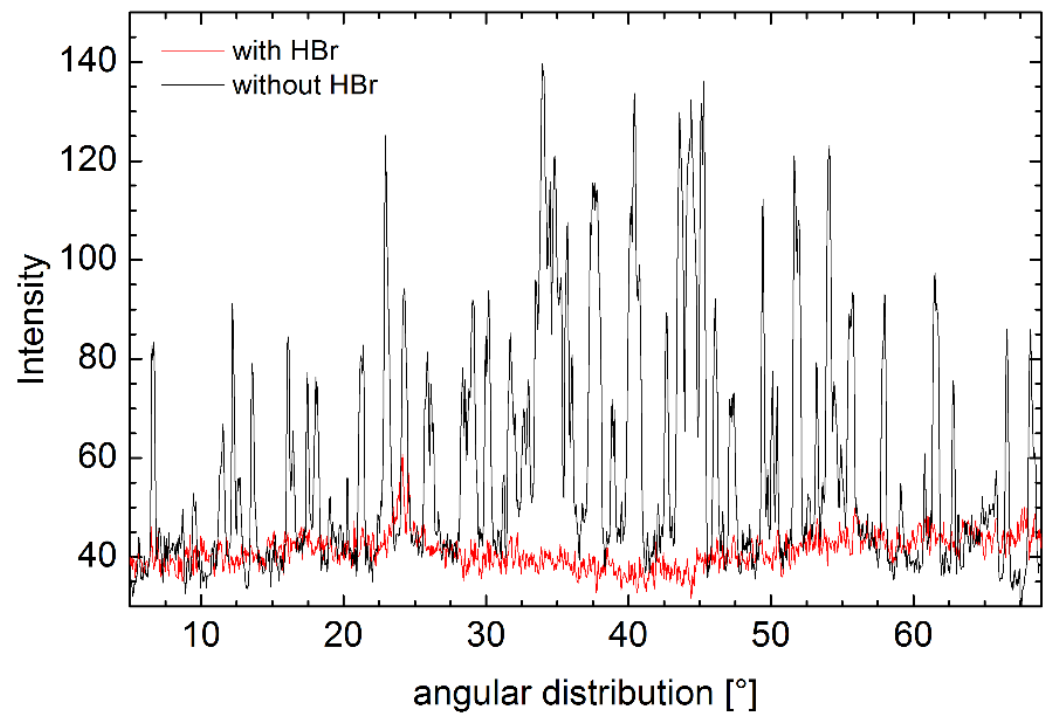

Figure S10. Angular intensity distribution of the $001 \mathrm{Bragg}$ reflection of $\mathrm{CH}_{3} \mathrm{NH}_{3} \mathrm{PbBr}_{3}$ as extracted from Figure $4 \mathrm{a}$ and $4 \mathrm{~b}$. (a) without $\mathrm{HBr}(\mathrm{b})$ with $\mathrm{HBr}$.
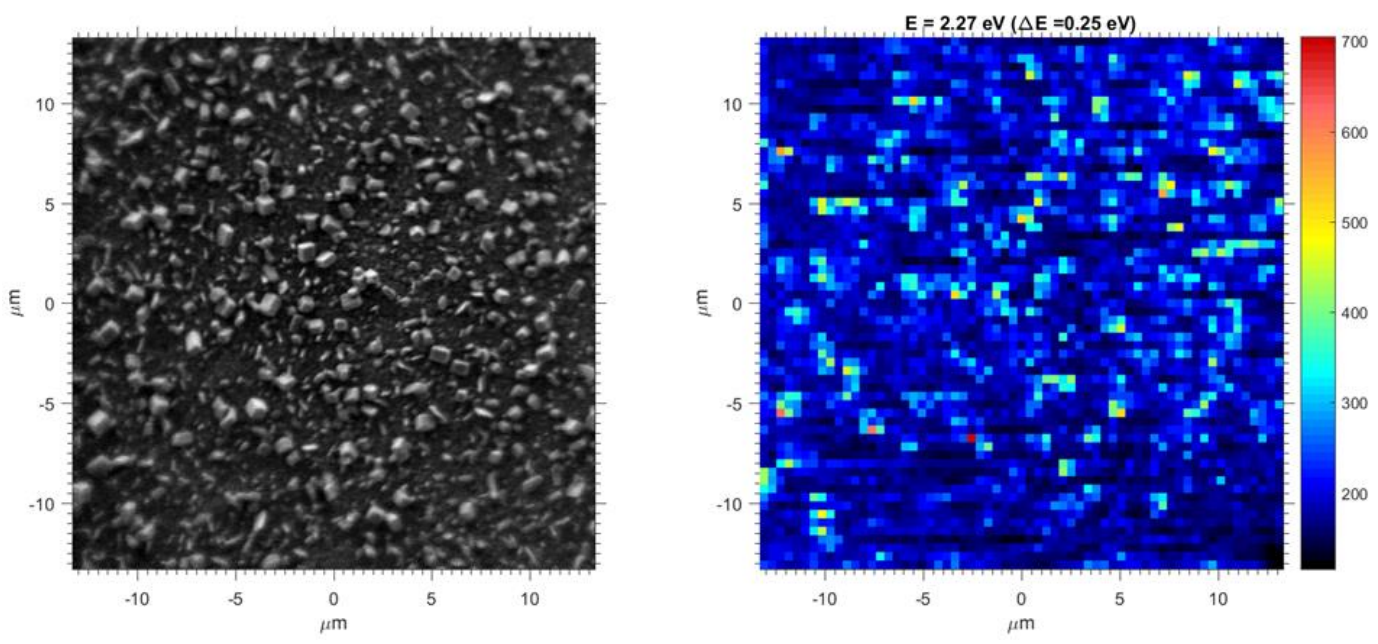

Figure S11. SEM micrograph (left side), and cathodoluminescence mapping (right side) acquired at $300 \mathrm{~K}$ on $\mathrm{CH}\left(\mathrm{NH}_{2}\right)_{2} \mathrm{PbBr}_{3}$ film involving $\mathrm{DMF}$ as a solvent. 